\title{
Maintenance or regression of the corpus luteum during multiple decisive periods of bovine pregnancy
}

\author{
M.C. Wiltbank ${ }^{1,6}$, R. Meidan ${ }^{2}$, J. Ochoa ${ }^{3}$, G.M. Baez ${ }^{1}$, J.O. Giordano ${ }^{4}$, J.C.P. Ferreira ${ }^{3}$, R. Sartori ${ }^{5}$ \\ ${ }^{1}$ Department of Dairy Science, University of Wisconsin-Madison, USA. \\ ${ }^{2}$ The Hebrew University of Jerusalem, Rehovot, Israel. \\ ${ }^{3}$ Department of Animal Production, São Paulo State University, Botucatu, SP, Brazil. \\ ${ }^{4}$ Department of Animal Science, Cornell University, Ithaca, USA. \\ ${ }^{5}$ Department of Animal Science, ESALQ, University of São Paulo, Piracicaba, SP, Brazil.
}

\begin{abstract}
In ruminants, there are specific times during the estrous cycle or pregnancy when the corpus luteum (CL) may undergo regression. This review has attempted to summarize the physiological and cellular mechanisms involved in CL regression or maintenance during four distinct periods. The first period is near day 7 when animals that are ovulating after a period of low circulating progesterone (P4), such as first pubertal ovulation or first postpartum ovulation, are at risk of having a premature increase in Prostaglandin F2 $\alpha$ (PGF) secreted from the uterus resulting in early CL regression and a short estrous cycle. The second period is when normal luteolysis occurs at day $18-25$ of the cycle or when the CL is rescued by interferon-tau secreted by the elongating embryo. The uterine mechanisms that determine the timing of this luteolysis or the prevention of luteolysis have been generally defined. Induction and activation of endometrial E2 receptors result in induction of endometrial oxytocin receptors that can now be activated by normal pulses of oxytocin. Of particular importance is the observation that the primary mechanisms are only activated through local (ipsilateral) and not a systemic route due to transfer of PGF from the uterine vein to the ovarian artery. In addition at the CL level, studies are providing definition to the cellular and molecular mechanisms that are activated in response to uterine PGF pulses or pregnancy. The third period that is discussed occurs in the second month of pregnancy (day 28-60) when undefined mechanisms result in CL maintenance of an ipsilateral CL but regression of a contralateral (opposite side from pregnancy) CL. The final period that is discussed is regression of the $\mathrm{CL}$ just prior to parturition. Although, cortisol from the fetus appears to be the primary initiator of luteolysis, PGF seems to be the final signal that causes regression of the CL. Thus, in all four periods, regression of the CL is likely to be caused by the direct actions of PGF that is secreted from the uterus. The uterine mechanisms that result in secretion of PGF seem to be normally inhibited during the early luteal phase, making short luteal phases not a normal event, and are altered during early pregnancy (day 18-25) resulting in prevention of luteolysis. During much of pregnancy, the mechanisms that cause PGF secretion from the uterus in response to oxytocin are intact but luteolysis does not normally occur, perhaps due to lack of efficient utero-ovarian transfer of PGF.
\end{abstract}

Keywords: interferon-tau, luteolysis, prostaglandin F2 $\alpha$.

\section{Introduction}

Alterations in the development, function, and regression of the corpus luteum $(\mathrm{CL})$ is a primary feature of the reproductive cycle and pregnancy of mammals. The primary role of the $\mathrm{CL}$ in these processes is due to secretion of the hormone progesterone (P4). From a historical perspective, the first detailed description of CL was by Regnier deGraaf (1641-1673) when he described the "globules" and explained that in rabbits "the number of globules equals the number of offspring from a particular mating" (deGraaf, 1672 cited by Jocelyn and Setchell, 1972). Later, Gustav Born (1851-1900), an excellent histologist, forwarded the idea that it was a gland of internal secretion, based on the high vascularity and lack of ducts, and speculated that it could be involved in pregnancy (see excellent reviews by Simmer, 1971; Magnus and Simmer, 1972). Two of his students, Ludwig Fraenkel and Vilhelm Magnus, independently tested this hypothesis in their own laboratories using slightly different experimental methods. In Germany, Ludwig Fraenkel performed bilateral ovariectomy or electrocautery of all $\mathrm{CL}$ in mated rabbits and found that they did not maintain their pregnancies (Fraenkel and Cohn, 1901). In Norway, Vilhelm Magnus performed galvano-cautery of all CL as well as bilateral ovarian removal in mated rabbits and also reported that pregnancy was not maintained (Magnus, 1901). Both researchers reached the same conclusion that the $\mathrm{CL}$ was essential for maintenance of pregnancy. Magnus later called the pregnancymaintaining endocrine secretion from the CL "differentieringsstofe" (differentiating stuff), the first name given to the hormone later known as progesterone (P4; Magnus, 1901). The initial reports were met with some skepticism. Fraenkel doggedly continued his research during the next decade on more than 160 rabbits eventually concluding that "Thus by the power of large numbers my thesis is proven: The ovary, in particular the CL, regulates the implantation and initial development of the embryo" (Fraenkel, 1910).

Possibly the most interesting biological properties of the CL are related to the incredible dynamics of this tissue. From the remains of the ovulated follicle, a new distinct structure is born (Smith et al., 1994). After differentiation, the CL is composed of multiple cell types (Wiltbank, 1994). The thecal and 
granulosa cells of the follicle, differentiate into the small and large steroidogenic cells of the CL. This transformation involves a steroidogenic change as these cells develop the enzymatic machinery to produce tremendous quantities of P4. From a mass perspective, the granulosa cell is only $10 \mu \mathrm{m}$ in diameter prior to the LH surge but increases to $38 \mu \mathrm{m}$ when it develops into the fully-functional bovine large luteal cell. This calculates to an increase in volume from about $500 \mu^{3}$ in the granulosa cell to almost $30,000 \mu \mathrm{m}^{3}$ in the large luteal cell, over a 50-fold increase in cellular volume (Wiltbank et al., 2012). In addition, there is rapid and extensive angiogenesis as the avascular follicular antrum remodels into a highly vascularized structure with every large luteal cell adjacent to multiple capillaries (Ellinwood et al., 1978) and the highest blood flow per gram of tissue in the body (Wiltbank et al., 1989). Then, abruptly, at specific, critical times during the cycle or pregnancy, the structure is put to death. For example, the bovine CL goes from a fully-functional structure of 4 to 6 $\mathrm{g}$, to a structure with little production of $\mathrm{P} 4$, low blood flow (Zalman et al., 2012), and structurally $<20 \%$ of the original volume, a process known as luteolysis or CL regression.

There are four time periods that will be discussed in this review article when CL regression commonly occurs in dairy and beef cattle (Fig. 1). The first potential luteolysis period that will be discussed is at about day 7. In most beef cattle and many dairy cattle, the first post-partum estrous cycle and rarely, other later estrous cycles, will have a short duration of $\sim 10$ days, due to early regression of the CL at $\sim$ day 7 . Luteolysis at this stage is not prevented by pregnancy but specific mechanisms prevent this early regression during most estrous cycles. The second period is the classical time for luteolysis in non-pregnant cows, near day 18-25. In pregnancy, maintenance of the CL during this period has been termed "Maternal Recognition of Pregnancy". There is a great deal of information available on the factors, events, and mechanisms related to luteolysis and prevention of luteolysis during this period. For example, there is a primary role for uterine prostaglandin F2 $\alpha$ (PGF), acting in a local manner, as the initiator of luteolysis during this classical period of luteolysis, with many of the uterine and luteal mechanisms that determine this process being clearly defined. In addition, a primary role for embryonic interferon-tau (IFNT) in preventing luteolysis has been clearly demonstrated with the precise mechanisms still an active area of research. The third period is during the second month of pregnancy or day 30 to 60 when CL regression can occur but is generally prevented through mechanisms that remain undefined. The final period of luteolysis occurs near the end of pregnancy with an increase in circulating estradiol (E2) followed by a tremendous increase in circulating PGF that is associated with an abrupt decrease in circulating P4 due to $\mathrm{CL}$ regression. Regression of the CL at this time is critical for the timing and physiology of the normal parturition process. The CL is the primary source of P4 throughout the estrous cycle and pregnancy, although during mid to late pregnancy the placenta secretes a variable amount of P4 in individual pregnant cows (Fig. 1). This review will emphasize the similarities and differences during these times of luteolysis, in terms of origin of PGF and intrauterine and intraluteal mechanisms that underlie each occurrence of luteolysis.

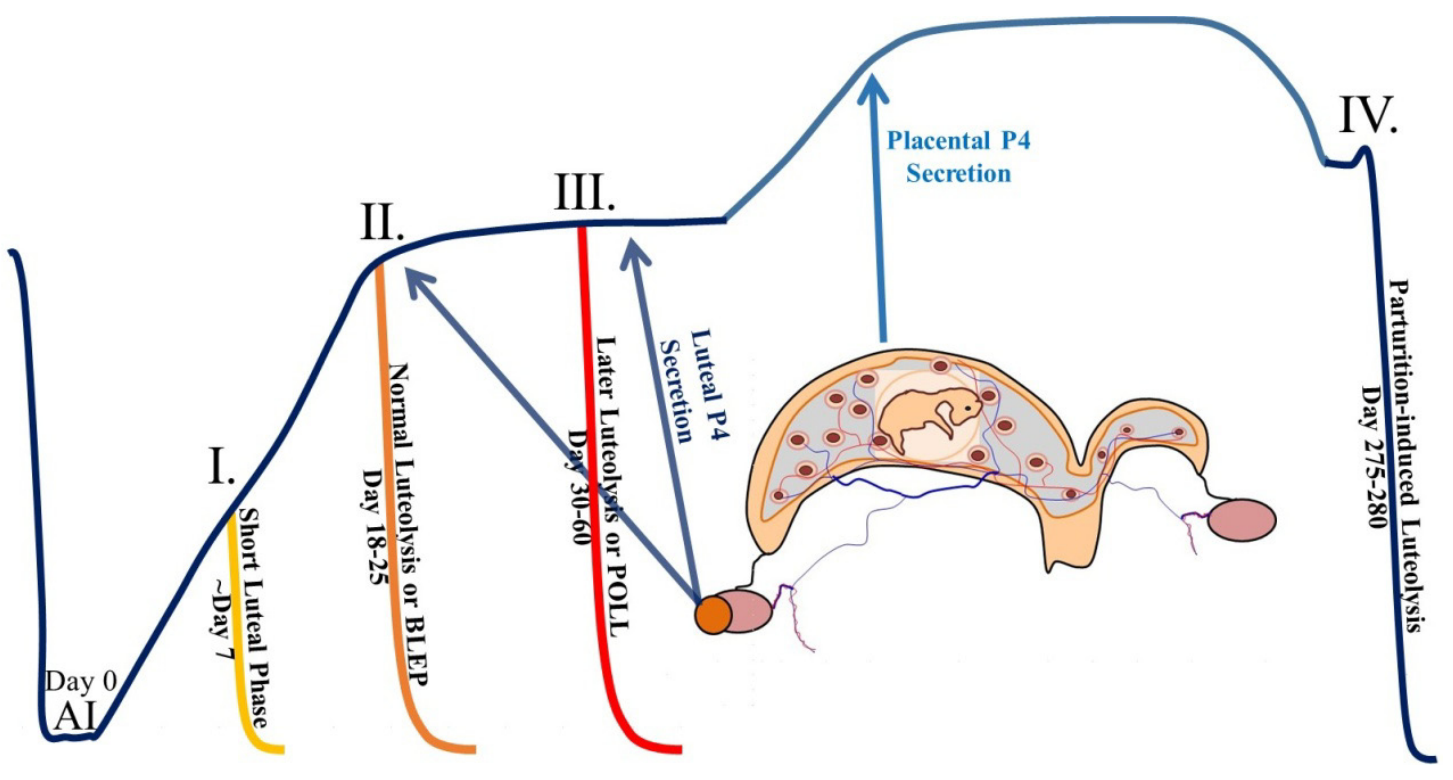

Figure 1. Theoretical diagram of circulating progesterone (P4) concentrations during pregnancy in cattle emphasizing the four key periods when luteolysis can occur. Period I - Luteolysis happens near day 7 and this leads to a short luteal phase. Pregnancy does not protect from this early luteolysis. Period II - Normal time of luteolysis at day 18-25 when prostaglandin F2 $\alpha$ pulses from the uterus regress the corpus luteum. During pregnancy, secretion of interferon-tau from the uterus leads to Blockade of Luteolysis in Early Pregnancy (BLEP) and maintenance of CL structure and function. Period III - Later luteolysis that can occur during the second month of pregnancy leading to pregnancy loss. During these stages of pregnancy, there are still undefined mechanisms that produce Prevention of Later Luteolysis (POLL) extending the CL lifespan through later pregnancy. Period IV - Parturition-induced luteolysis occurs about 2 days before parturition and allows continuation of the cascade of events that produce parturition. 


\section{Period I: Short luteal phase and early CL regression - day 5-7}

In ruminants, short cycles, due to an inadequate luteal phase, occur in some specific physiological situations. For example, short cycles have been documented in cattle and sheep following the first ovulation after puberty (Berardinelli and Butcher, 1979; Berardinelli et al., 1979), following the first ovulation post-partum in dairy and beef cattle (Garverick et al., 1992b), and after the first ovulation of the breeding season in ewes that were previously not cycling (Hunter, 1991). For example, in beef cattle that have been induced to ovulate by calf removal or treatment with an ovulation inducing agent, such as human chorionic gonadotropin (hCG) or gonadotropinreleasing hormone $(\mathrm{GnRH})$, there is generally a very high incidence of shortened luteal phases $(\sim 80 \%)$. In dairy cattle, the first post-partum ovulation can be followed by a short cycle, but a much lower incidence has been reported $(\sim 27 \%$; Table 1$)$. It seems obvious that the presence of short cycles can reduce fertility since pregnancies are unlikely to occur because the embryo has generally not hatched from the zona pellucida and definitely not undergone embryonic elongation at the time of this early CL regression. Thus, fertility is absent in these cows, whether or not they have had fertilization and an appropriately-developing embryo.

Table 1. Incidence of short luteal phases or short cycles in dairy cattle.

\begin{tabular}{lll}
\hline Type of cattle & Short cycle $(\%)$ & Reference \\
\hline Dairy cattle & $76 / 281(27.1 \%)$ & \\
Lactating Holstein & $16 / 118(13.6 \%)$ & Fallon (1958) \\
Lactating Holstein & $9 / 27(33.0 \%)$ & Hinshelwood et al. $(1982)$ \\
Lactating Holstein & $5 / 18(27.8)$ & Stevenson and Britt $(1979)$ \\
Lactating Friesian & $21 / 39(53.8 \%)$ & Savio et al. $(1990)$ \\
Lactating Holstein & $176 / 645(27.3 \%)$ & Staples et al. $(1990)$ \\
Lactating Holstein & $303 / 1,128(26.9 \%)$ & Royal et al. $(2000)$ \\
Total dairy & & \\
\hline
\end{tabular}

It is also clear that the short cycle is due to a shortened lifespan of the CL, for example in cattle, the CL regresses at 6-7 days after previous estrus. The cow then shows a subsequent estrus at 8-11 days after the previous estrus. As evidenced by the physiological conditions that result in short cycles, one of the primary risk factors for the shortened CL lifespan is an extended period without circulating $\mathrm{P} 4$ prior to the ovulation that produces the inadequate $\mathrm{CL}$.

To understand the physiological mechanisms that produce the short estrous cycle, a number of different ruminant experimental models have been utilized. One model that has been utilized is the ewe in the non-breeding season that is induced to ovulate with GnRH treatment (Hunter, 1991; $0.25 \mu \mathrm{g}$ every $2 \mathrm{~h}$ for 18-24 h, followed by an ovulatory dose of GnRH, 125 $\mu \mathrm{g})$. Pretreatment for $36 \mathrm{~h}$ with $\mathrm{P} 4$ resulted in $100 \%$ of ewes with a normal CL lifespan, whereas, induction of ovulation with this protocol without pretreatment with $\mathrm{P} 4$ resulted in $\sim 70 \%$ shortened luteal phases. In ewes, CL regression occurs between day 4 and 6 after the induced LH surge (Robinson et al., 2008). In beef cattle, induction of the first post-partum ovulation by early weaning or temporary calf removal or by using hormonal treatments, such as GnRH or hCG, results in a high percentage of cows with short cycles, whereas pretreatment with $\mathrm{P} 4$ or progestogens before these induction procedures prevents these short cycles (Copelin et al., 1988; Salfen et al., 1995). Finally, in cycling dairy heifers or cows, a high percentage of short cycles is induced if cows are given a premature treatment with GnRH following induction of luteolysis with PGF ( 0 or $24 \mathrm{~h}$ after PGF given on day 6 or 7 of the estrous cycle; Peters and Pursley, 2003; Rantala et al., 2009). Each of these models is characterized by inadequate circulating E2 during the proestrous period, generally ovulation of a smaller follicle, production of a CL with a shortened lifespan, and a short estrous cycle.

Using these animal models, the mechanisms that produce early regression of the CL have generally been divided into effects related to: 1) the preovulatory follicle, 2) the CL, and/or 3) the uterus. Related to the follicle, there are clear differences between the preovulatory follicle of ewes or cattle that have a shortened luteal phase including: decreased LH receptors in granulosa cells and decreased follicular E2 production, as evidenced by decreased circulating E2 or decreased E2 in follicular fluid (Hunter et al., 1986; White et al., 1987; Inskeep et al., 1988; Braden et al., 1989a, b). Thus, follicular function prior to short estrous cycles is clearly defective, and preovulatory circulating E2 concentrations are reduced in each of the physiological situations that result in a shortened luteal phase.

Related to the CL, initial development and function of the CL were similar until 4 days after the LH surge in ewes with normal or shortened luteal phases. After that time, the CL regressed rapidly in a manner that closely resembled the timing of $\mathrm{CL}$ regression at the end of the luteal phase (Hunter et al., 1989). In beef cattle, the patterns of P4 were similar until day 5 after estrus and subsequently there was a rapid decrease in circulating $\mathrm{P} 4$ as CL regression ensued (Copelin et al., 1987). One suggestion has been that short-lifespan CL lack gonadotropin support or gonadotropin responsiveness. Contrary to this idea, there were no differences in $\mathrm{LH}$ receptors or adenylate cyclase activity in early CL that were destined for shortlifespan vs. longer lifespan (Smith et al., 1996). In addition, there were no detectable differences in $\mathrm{LH}$ secretion during the early luteal phase for these two types of animals (Garverick et al., 1988). Further, treatments with luteotropins, such as treatment with 
GnRH pulses or hCG, were unable to overcome the shortened luteal lifespan (Smith et al., 1996). In addition, there are no differences in PGF responsiveness of CL destined to have normal or short lifespan (Copelin et al., 1988). Thus, although the CL clearly regresses prematurely in cows or ewes with a short cycle, there is no evidence that the CL is functionally incompetent or that it regresses due to mechanisms that are internal to the $\mathrm{CL}$.

Finally, most evidence is consistent with a primary role for the uterus in shortened luteal lifespan in ruminants. The most definitive experiments utilized hysterectomized cattle or ewes that were induced to ovulate. Intact cows had an estrous cycle of 8.8 days, whereas, hysterectomized cows that were treated similarly had a prolonged functional CL and did not return to estrus (Copelin et al., 1987). Similarly, hysterectomy resulted in normal CL function in ewes destined to have short-lived CL (Southee et al., 1988). Thus, it seems clear that the shortened luteal lifespan is due to a direct effect of the uterus. Active immunization against PGF (Copelin et al., 1989) or inhibition of PGF secretion were both effective in extending the CL lifespan and increasing P4 secretion by the CL, indicating that uterine PGF is the primary cause of the shortened luteal phase. Consistent with this idea, cows destined to have short-lived CL have early secretion of PGF from the uterus (Zollers et al., 1991) and an early increase in circulating metabolite of PGF that begins near the time of the first increases in circulating E2 during the first follicular wave (Southee et al., 1988; Hunter et al., 1989; Cooper et al., 1991; Hunter, 1991; Garverick et al., 1992b). In addition, intrauterine infusion of IFNT, the protein that normally causes maintenance of the CL during pregnancy in ruminants, can prevent short luteal phases (Garverick et al., 1992a). At least part of the action of IFNT is a reduction in uterine secretion of PGF. Thus, all of these diverse types of evidence clearly point to premature secretion of PGF from the uterus as the direct initiator of premature luteolysis in cows with a short-lived CL.

There also seems to be a critical role for E2 from the follicle in development of the mechanisms associated with a shortened CL lifespan. Reduced preovulatory E2 can produce a short CL lifespan (Vasconcelos et al., 2001; Peters and Pursley, 2003; Rantala et al., 2009), even in animals with elevations in P4 prior to the preovulatory period. However, supplementation of early postpartum beef cattle with E2 alone was not sufficient to restore normal luteal phases but they required both elevated $\mathrm{P} 4$ prior to the preovulatory period and elevated E2 during the preovulatory period to have normal CL lifespan (Sa et al., 2009). Thus, elevated circulating $\mathrm{P} 4$, followed by a decrease in P4 and an increase in circulating E2 are important components that regulate a lack of development of oxytocin responsiveness during the early luteal phase and prevent short-lived CL, in normal physiological situations (Hunter et al., 1989; Hunter, 1991; Beard and Hunter, 1996). In addition, there is a critical role for E2 from the dominant follicle of the first follicular wave, after ovulation, in the mechanisms that underlie premature PGF secretion in short luteal phases (Beard and Hunter, 1994). This is evidenced by the fact that treatment with steroid-stripped follicular fluid inhibited growth of the dominant follicle and premature development of oxytocin-responsiveness in ewes destined to have a short-lived CL. Thus, it seems clear that elevated $\mathrm{P} 4$ followed by elevated E2 in the absence of $\mathrm{P} 4$ are critical for preventing premature E2-induction of oxytocin responsiveness during the early luteal phase and induction of early luteolysis.

Figure 2 shows a theoretical, simplified model comparing changes in the uterine endometrial cells during the early luteal phase in animals destined to have CL with normal or shortened CL lifespan. In animals destined to have a normal lifespan, at day 5-7 the endometrial cells do not have E2 responsiveness, due to action of P4 and E2 prior to ovulation. Therefore, even though there is an increase in E2 during the first follicular wave, this E2 does not have an effect on the uterine endometrial cells, preventing induction of oxytocin receptors, and preventing premature luteolysis. However, in animals that will have a short life-span CL, E2 responsiveness is present in the uterine endometrial cells and the increase in circulating E2 during the first follicular wave allows induction of oxytocin receptors, with subsequent oxytocin-induced PGF secretion, and premature luteolysis. These events resemble the events that occur at day 17-20 in the uterine endometrial cells of animals destined to have normal CL lifespan.

\section{Period II: Normal luteolysis: role of uterus and PGF - days 18-25 of estrous cycle}

Under normal conditions, if no fertilization occurs during an estrous cycle, the $\mathrm{CL}$ will regress at $\sim 18$-19 days after previous estrus. This process is referred to as normal luteolysis, and involves a decrease in P4 (functional luteolysis) as well as a decrease in CL volume and blood flow (structural luteolysis). Functional luteolysis occurs over a period of $\sim 24 \mathrm{~h}$ in individual cows or sheep, if luteolysis is designated as circulating P4 $<1 \mathrm{ng} / \mathrm{ml}$, or in $\sim 32 \mathrm{~h}$ if $<0.5 \mathrm{ng} / \mathrm{ml}$ is used as the designation for functional luteolysis (Ginther et al., 2007).

The role of the uterus in determining the lifespan of the CL was first demonstrated in guinea pigs by showing that $\mathrm{CL}$ were maintained after hysterectomy (Loeb, 1927). In ruminants, a clear demonstration of the role of the uterus in luteolysis was published in 1956 by using hysterectomy of both sheep and cattle (Wiltbank and Casida, 1956). Sheep and cattle that had complete removal of the uterus did not return to estrus and CL lifespan was greatly prolonged. For example, sheep with CL marked with India ink were still present at 52, 53, 76, 98, and 107 days after hysterectomy. Similarly, cows that had complete hysterectomy had large, marked CL present at 27, 98, and 154 days after hysterectomy (Wiltbank and Casida, 1956). Thus, complete removal of uterus led to maintenance for a long but not yet clearly defined time. Interestingly, when part of the uterus (ipsilateral to the CL) remained after the hysterectomy surgery, CL regression occurred and 
animals returned to estrus. Numerous hysterectomy and unilateral hysterectomy studies have been performed and the role of the uterus in luteolysis is clearly delineated (Collins et al., 1966). In addition, ipsilateral (uterine horn on the same side as CL) hysterectomy invariably prolonged the lifespan of the CL, while contralateral hysterectomy consistently failed to affect the CL lifespan (Inskeep and Butcher, 1966).

It was soon realized that the uterine-derived luteolysin that regressed the CL was able to arrive at the ipsilateral CL through a local veno-arterial transfer pathway. The ovarian artery in ruminants is extremely convoluted and in close apposition to the uterine vein, thus allowing transfer of the uterine luteolysin, PGF, to the ovarian artery (Ginther and Del Campo, 1974; Mapletoft et al., 1976a). In an experiment in which the convoluted ovarian artery was separated from the uterine vein, three out of four ewes maintained the CL until slaughter on day 25 (Barrett et al., 1971). Experiments involving unilateral hysterectomy and subsequent cross-over anastomosis of the uterine veins provided strong evidence for the local delivery of a uterine luteolysin to the ovarian artery (Mapletoft et al., 1976a). When the uterine vein from the intact horn was joined with the uterine vein on the hysterectomized side with the CL, the CL regressed at the normal time clearly demonstrating the involvement of the local uteroovarian, veno-arterial pathway in luteolysis during this period (Mapletoft et al., 1976a).

The possibility that PGF was the luteolytic agent was first suggested during a reproductive workshop in 1965 (Hansel, 1966). Evidence was subsequently provided in rats that treatment with PGF2 $\alpha$ produced luteolysis (Gutknecht et al., 1969; Pharriss and Wyngarde 1969). Thereafter, a series of experiments by McCracken using auto-transplanted ovaries demonstrated the luteolytic effect of PGF in sheep (Goding et al., 1967; McCracken, 1971). There are now multiple types of evidence that convincingly demonstrate that PGF is the uterine luteolysin in ruminants (Knickerbocker et al., 1988). First, PGF is abundantly produced in the uterus of non-pregnant ruminants (McCracken et al., 1972) and there are increased concentrations of PGF in uterine venous drainage, uterine flushings, and uterine tissue near the expected time of luteolysis (Wilson et al., 1972). Second, pulses of uterine vein PGF and the circulating concentrations of the PGF metabolite (PGFM; 15-Keto13,14-dihydro-PGF2 $\alpha$ ) correspond to the time of decreasing P4 in non-pregnant heifers (Kindahl et al., 1976; Ginther et al., 2007). Third, inhibition of uterine PGF production prevents spontaneous luteolysis in both ewes and heifers (Lewis and Warren, 1977). Fourth, passive immunization with antibodies that are specific to PGF prolonged the lifespan of the CL (Fairclough et al., 1981). Fifth, there is good evidence that PGF can be efficiently exchanged from the uterine vein to the ovarian artery in sufficient quantities to make the local mechanisms physiologically feasible (Lamond et al., 1973; McCracken et al., 1981). Finally, treatment with pulses of PGF that mimic the natural PGF pulses can induce complete luteolysis that resembles natural luteolysis (Schramm et al., 1983; Ginther et al., 2009; Atli et al., 2012). Thus, evidence is compelling that luteolysis in ruminants is initiated by PGF coming from the non-pregnant uterus.

The pattern of PGF secretion has clearly been shown to be pulsatile. Figure 3 shows a typical pattern for PGFM, oxytocin, and P4 during luteolysis in an individual cow undergoing luteolysis between day 18 and 20. As shown, P4 concentrations decrease rapidly with most of the decrease occurring in a $24 \mathrm{~h}$ period. The decrease in $\mathrm{P} 4$ is associated with four distinct pulses of PGF, which are reflected in the circulating PGFM pulses shown in Fig. 3. Finally, pulses of circulating oxytocin occur routinely prior to luteolysis with little effect on circulating PGFM. However, during the time of luteolysis, each oxytocin pulse is associated with a pulse of PGFM. This pattern emphasizes the critical role for oxytocin responsiveness, i.e. oxytocin receptors, in production of PGFM pulses and ultimately luteolysis.

The cellular mechanisms within the uterine endometrial cells that produce the PGF pulses was shown in a simplified manner in Fig. 2 and is shown in greater detail in other reviews (McCracken et al., 1999; Spencer and Hansen, 2015). Clearly the induction of E2 receptors has a central role in the mechanisms that initiate these pulses. During most of the normal luteal phase, expression of E2 receptors in endometrial cells is inhibited by elevated circulating $\mathrm{P} 4$ acting on $\mathrm{P} 4$ receptors in these cells. Near the end of the luteal phase, elevated $\mathrm{P} 4$ begins to downregulate $\mathrm{P} 4$ receptors and this allows E2 receptor expression near the time of luteolysis (Spencer and Bazer, 1995; Spencer et al., 1995). Initiation of luteolysis is dependent upon activation of these E2 receptors by the increase in circulating E2 that accompanies development of a dominant follicle in the preovulatory follicular wave. This is illustrated by the delay in luteolysis that is caused by elimination of circulating E2 by either ultrasound-guided ablation of follicles (Araujo et al., 2009) or inhibition of follicle growth by treatment with steroid-stripped follicular fluid (Salfen et al., 1996). This delay in luteolysis is prevented by treatment with low doses of E2 (Salfen et al., 1996; Araujo et al., 2009). One of the major actions of E2 in the endometrial cell at this time is the induction of oxytocin receptors (Robinson et al., 2001). After induction of oxytocin receptors, uterine endometrial cells produce pulses of PGF secretion in response to the natural pulses of oxytocin that occur during the day (Ginther et al., 2012).

Thus, natural luteolysis is connected to distinct PGF pulses from the uterine endometrial cells that are induced by oxytocin pulses. Studies using $\left[{ }^{3} \mathrm{H}\right]-\mathrm{PGF}$ have indicated that during the peak of a PGF pulse, $\sim 10 \%$ of secreted PGF will be transported from the uterine vein to the ovarian artery (Lamond et al., 1973; McCracken et al., 2010). How this PGF is transported between the vascular systems has been delineated in elegant recent studies that showed expression of a specific PG Transporter in the three layers, tunica intima, tunica media, and tunica adventitia, of both the utero-ovarian vein and the ovarian artery (Lee et al., 
2010; McCracken et al., 2011). The primary PG Transporter is a member of the organic solute carrier family that has 12-transmembrane domains and is termed SLCO2A1, also known as OATP2A1 (Kanai et al., 1995; Schuster, 1998, 2002). A specific inhibitor of the PG Transporter, DIDS, was able to block luteolysis but did not change expression of E2 receptor, oxytocin receptor, Cox-2, PG transporter, or uterine production of PGF (Lee et al., 2013). Thus, all luteolytic mechanisms were intact but still efficient PGF transport, in this case out of the endometrial cells, is needed for the luteolytic process.
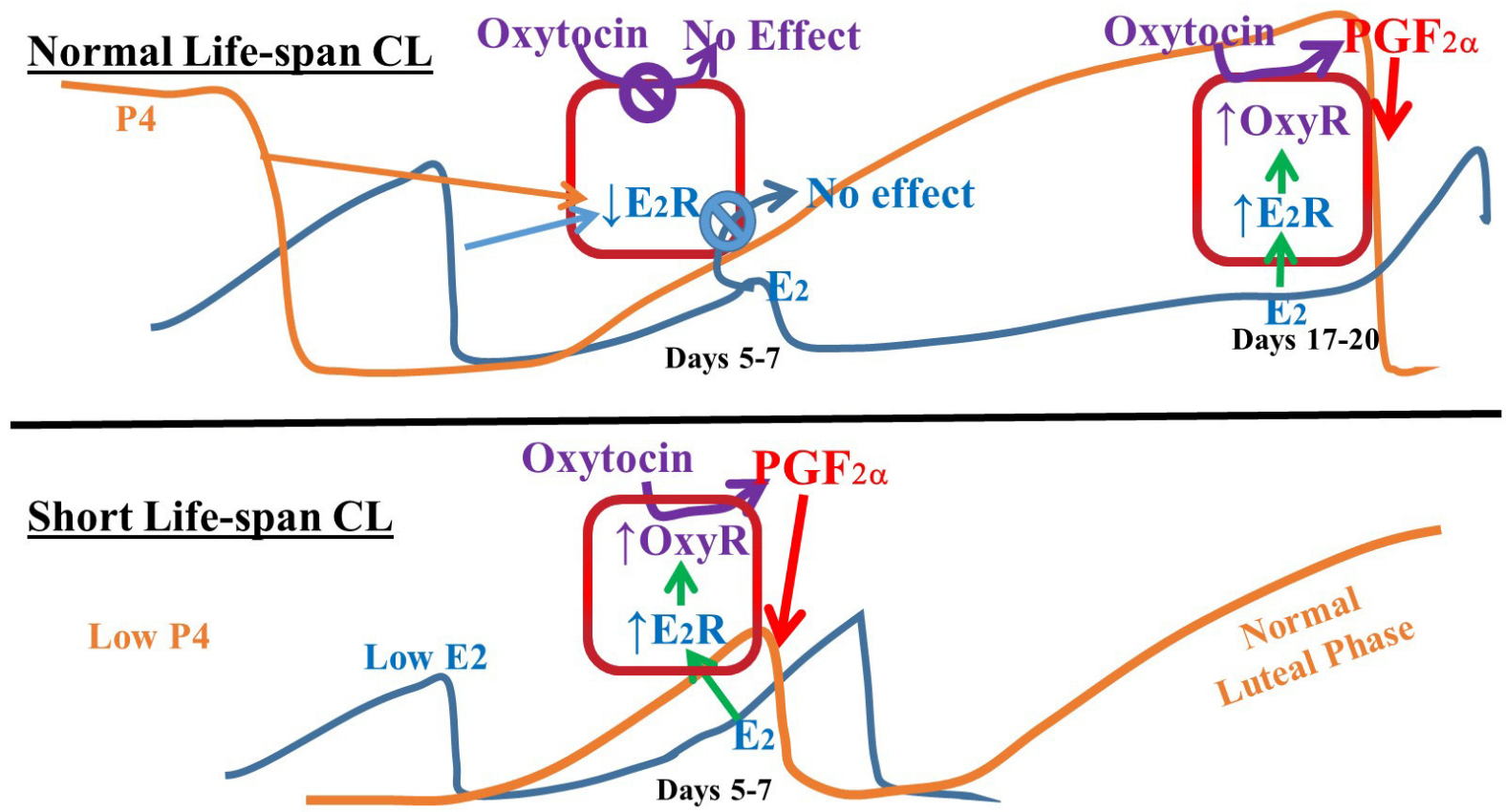

Figure 2. Proposed physiological model for the mechanisms that produce a CL with a short or normal life-span. The cell that is shown is the uterine endometrial cell at day 5-7 or at day 17-20 during the normal CL lifespan. Text discusses the mechanisms shown in the figure. E2R = estradiol receptor; OxyR = Oxytocin Receptor; P4 = progesterone; E2 = estradiol-17 $\beta$; PGF2 $\alpha=$ prostaglandin $\mathrm{F} 2 \alpha$.

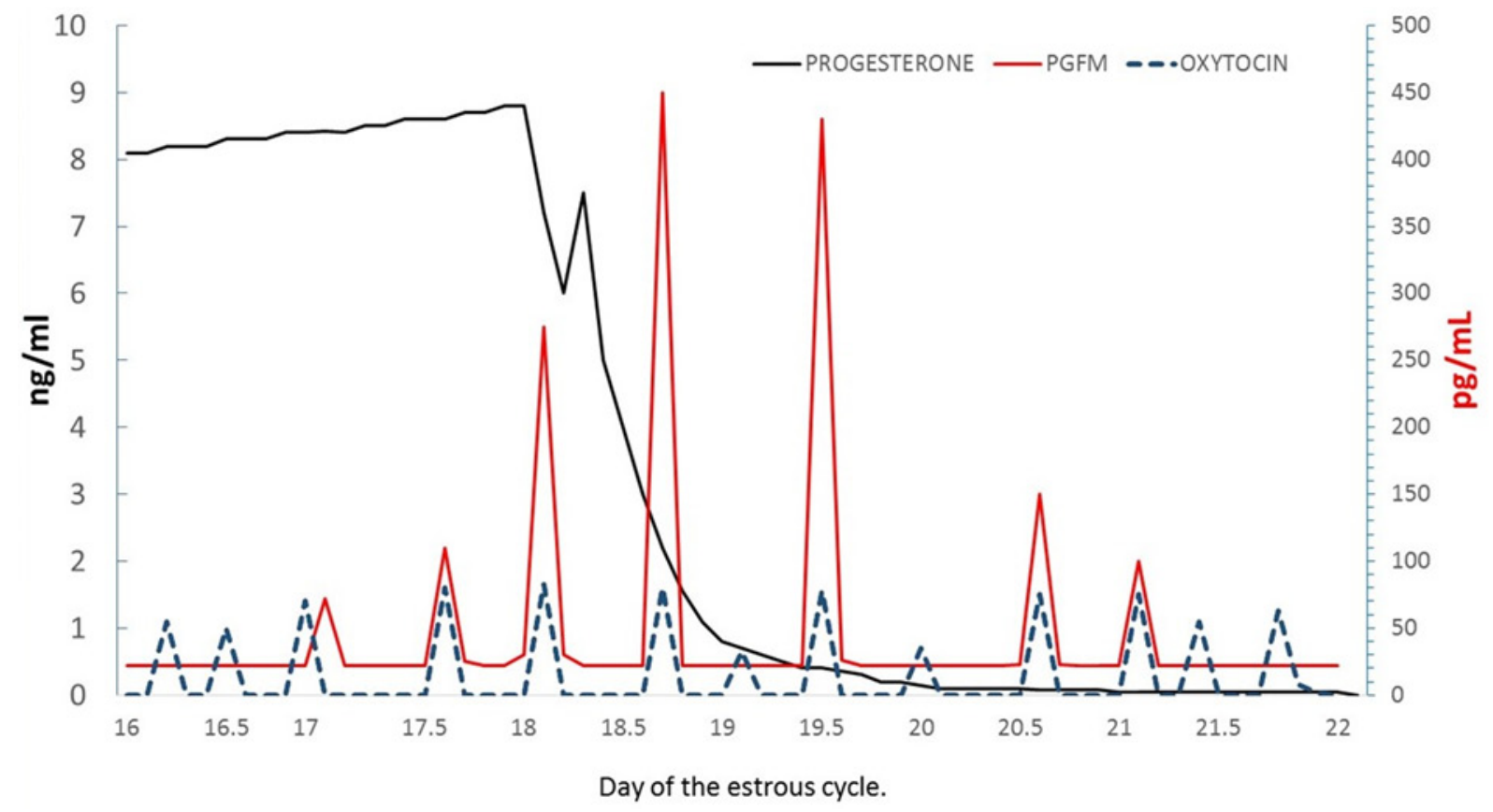

Figure 3. Diagram of the patterns of circulating progesterone, oxytocin, and PGFM concentrations during the time of luteolysis in cattle. As luteolysis approaches, pulses of oxytocin act on the uterine endometrial cells to cause production of pulses of PGF, detected as PGFM in the peripheral circulation, and these pulses cause the decrease in circulating P4 and luteolysis. 
Once PGF reaches the CL, some of the most exciting cellular and molecular processes are activated, resulting in the complete luteolytic process. Although many studies have evaluated the processes that are involved in the biological action of PGF in the CL, most of these studies utilized supra-physiological doses of PGF. Recent studies have either monitored the mechanisms that follow natural PGF pulses (Ginther and Beg, 2009) or used more physiological pulses of PGF in an attempt to mimic and synchronize the mechanisms that occur during natural luteolysis (Ginther et al., 2009; McCracken et al., 2012). Our laboratory has given intrauterine injections of low doses of PGF in order to evaluate gene expression in response to synchronized PGF pulses (Atli et al., 2012). Figure 4 shows a simplified view of some of the gene expression changes that are happening within the $\mathrm{CL}$ following each PGF pulse. Although only a single cell is shown, ostensibly a large luteal cell since they contain most of the PGF receptors, it should be understood that multiple cell types and complex processes are occurring during luteolysis.

Five key types of gene expression events are illustrated in response to each PGF pulse. The early response gene, Jun, is shown to increase in response to each PGF pulse, which is representative of many early response genes (Atli et al., 2011). The PGF synthesis pathways are complex but two genes are shown, one involved in PGF production, prostaglandin $\mathrm{G} / \mathrm{H}$ Synthase-2 (PTGS2), and one involved in PGF metabolism, prostaglandin Dehydrogenase (PGDH). After the first PGF pulse both genes are stimulated, in spite of the fact that PGDH will eventually be inhibited during the luteolysis process, after the third pulse. The continued induction of the PGF synthesis pathways and the eventual inhibition of the PGF metabolism pathways will allow intraluteal PGF production and an autoamplification pathway for PGF production (Tsai and Wiltbank, 1996, 1997). Production of P4 is eventually inhibited but, similar to PGDH, steroidogenic acute regulatory protein or StAR, is stimulated by the first pulse of PGF but then inhibited by pulse 2, 3, and 4. Eventually all of the steroidogenic pathway genes are inhibited but StAR is the most acutely regulated.

Many genes that are associated with immune function are stimulated during the luteolytic process. Some may be due to production of immunomodulatory molecules from luteal cells and eventually increased expression is due to influx of immune cells into the CL during the luteolytic process. Thus, immune-related genes begin to be stimulated mostly after the 2nd PGF pulse and continue to increase after the 3rd and 4th pulses. Alterations in angiogenic pathways are a key part of the luteolysis process. Expression of VEGFA is shown as an example of alterations in angiogenesis during pulses of PGF. After the first pulse there is a paradoxical increase in VEGF mRNA expression and then all subsequent pulses produce inhibition of genes that are involved in stimulating blood vessel formation and function.

Thus, this simple diagram illustrates some of the key pathways that are being activated during the luteolytic process. Transcriptional pathways, such as the ones regulated by some of the early response genes, are activated and are likely to mediate the subsequent changes in gene expression. Steroidogenesis is decreased as the CL proceeds through functional luteolysis. Structural luteolysis proceeds as blood vessels begin to breakdown and immune cells are involved in key structural and functional changes that occur during luteolysis. Finally, although PGF pulses from the uterus are the initiators of luteolysis, intraluteal production of PGF is probably important for expression of the complete luteolytic pathways.

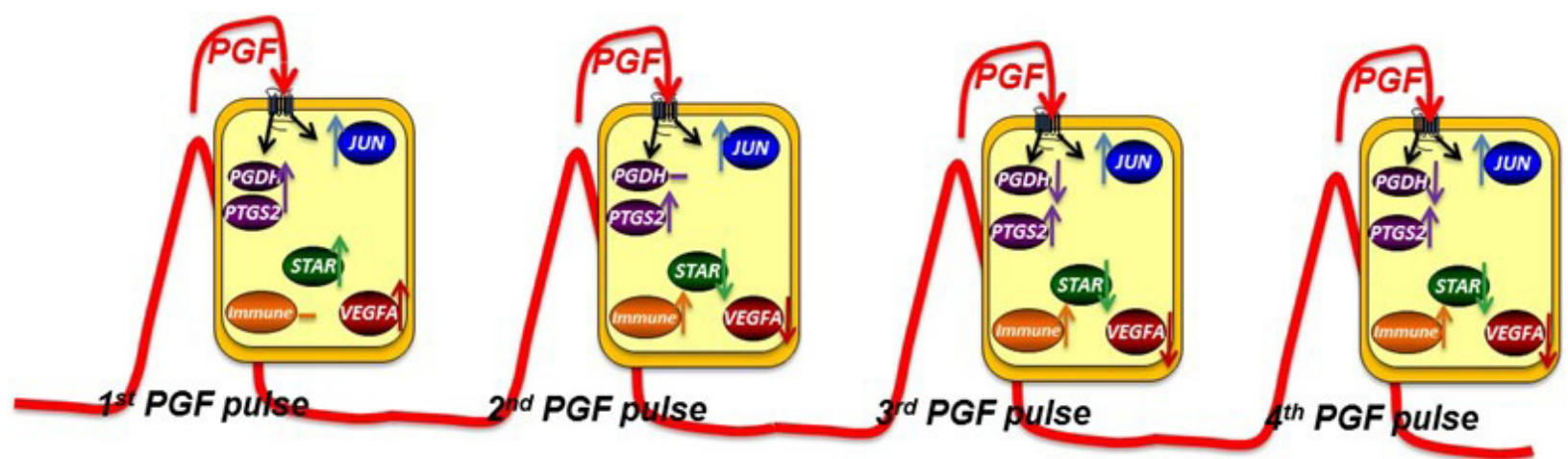

Figure 4. Physiological model of the changes in gene expression within the CL during intrauterine injection of low doses of PGF, designed to mimic physiological pulses of PGF occurring during luteolysis. See text for details.

Period II. Blockade of luteolysis in early pregnancy day 18-25 of pregnancy

Pregnancy causes a blockade of luteolysis that has been sometimes termed "Maternal recognition of pregnancy". In ruminants, the pregnancy protects the CL from regression through local and not systemic pathways. This has been clearly demonstrated in a series of elegant experiments with isolated horns or vascular anastomoses. For example, transfer of embryos into a surgically-isolated uterine horn resulted in CL regression if the embryo was transferred contralateral to the CL but the CL was maintained if the embryo was transferred ipsilateral to the pregnancy in both cows (Del Campo et al., 1977) and ewes (Moor, 1968). In surgically-isolated horns, surgical anastomosis of the main uterine vein from the gravid side to the uterine vein on the non-gravid side resulted in maintenance of 
the CL on the non-gravid side in both ewes (Mapletoft et al. 1975) and cows (Del Campo et al., 1980). This demonstrated that the pregnancy signal was local and not systemic and was carried in the local uterine vein. Similarly, anastomoses of the ovarian artery from the gravid side to the non-gravid side resulted in CL maintenance (Mapletoft and Ginther, 1975; Mapletoft et al., 1976c) demonstrating that the signal passed from the uterine vein to the ovarian artery, only on the same side and not the opposite side from the pregnancy. Thus, it is clear that even though some pregnancy signals may escape the uterus, the critical pregnancy signal that protects the CL in ruminants during early pregnancy is acting locally by passing from the uterine vein to the ovarian artery and not through the systemic circulation. In addition, these studies demonstrated that maintenance of pregnancy is not just the absence of a signal, such as the absence of PGF pulses, but the active blockade of luteolysis. This is clear since uterine vein blood from the non-gravid horn is still present when the blood from uterine vein of the gravid horn is added and the CL is protected. The two ewes that had clots in the anastomosis had normal CL regression.

Early embryo transfer experiments showed that if the embryo was flushed from the uterus on day 13 or before in the ewe (Moor and Rowson, 1966; Moor et $a l ., 1969)$ or day 16 or before in the cow (Northey and French, 1980) there was normal timing of CL regression. In contrast if the embryo was flushed from the uterus after this "critical period", the CL lifespan was extended, demonstrating the time when the pregnancy signal began to be secreted by the embryo. In cyclic ewes, intrauterine infusion of homogenates or secreted proteins from day 14-15 embryos extended CL lifespan, whereas, homogenates of day 21-25 embryos did not alter CL lifespan (Rowson and Moor 1967; Godkin et al., 1984b), demonstrating the limited interval during pregnancy when the signal is secreted by the conceptus. The active principal in the homogenates was heat and protease-labile, and had properties consistent with a low molecular weight protein (Rowson and Moor, 1967; Martal et al., 1979; Godkin et al., 1982). Later studies showed that a single protein, termed ovine or bovine trophoblast protein-1 at the time and later IFNT, was solely responsible for maintenance of the CL during pregnancy in ruminants (Godkin et al., 1984a, 1997; Thatcher et al., 1984).

Thus, during the critical period of day 17 to 25 in cattle, the embryo is dramatically elongating, nourished by histotroph in the uterine lumen. The ruminant trophectoderm secretes IFNT during elongation of the early embryo and IFNT has been shown to be the definitive signal for CL maintenance during early pregnancy (Roberts, 1996; Bazer et al., 1997). In uterus, IFNT acts in a paracrine manner to prevent expression of estrogen receptor alpha and oxytocin receptor in endometrial luminal epithelium and superficial glandular epithelium, thereby altering release of luteolytic pulses of PGF (Spencer et al., 2007b). Interferon-tau also stimulates expression of specific genes, termed interferon-stimulated genes (Antoniazzi et al., 2013), in the uterus (Johnson et al., 1999) and in peripheral tissues such as the CL (Oliveira et al., 2008; Bott et al., 2010) and peripheral blood cells (Gifford et al., 2007; Shirasuna et al., 2012). Thus, circulating IFNT that escapes the uterine lumen might prevent CL regression by acting directly on $\mathrm{CL}$ and this action could be independent or synergistic with the actions of IFNT on uterine PGF secretion.

Previous studies have also indicated that the CL of pregnancy has reduced sensitivity to PGF (Silvia and Niswender, 1984, 1986; Silvia et al., 1984a). Much of this resistance to PGF action is ascribed to actions of prostaglandin E2 and E1 (termed PGE in this proposal) coming from the pregnant uterus. Indeed, PGE can block natural or PGF-induced luteolysis either in vivo or in vitro (Michael et al., 1993; Miyamoto et al., 1993; Fortier et al., 2004; Weems et al., 2011). In addition, recent studies showed that endocrine delivery of recombinant ovine IFNT, via uterine or jugular vein, protected the ovine CL from the luteolytic actions of PGF, maintaining intraluteal and circulating P4 and CL volume (Antoniazzi et al., 2013).

It is clearly established that P4 from the CL is essential for maintenance of pregnancy and that IFNT from the elongating embryo is the definitive signal for CL maintenance during early pregnancy (Roberts, 1996; Bazer et al., 1997; Spencer et al., 2007b; Dorniak et al., 2013). At this time, there is still substantial controversy regarding the precise endocrine pathways involved in maintenance of the CL by IFNT with three potential pathways being most supported but by different research groups. First, the classical mechanism is that IFNT changes uterine gene expression resulting in reduced pulses of PGF and thus lack of luteolysis (Thatcher et al., 1984; Knickerbocker et al., 1986; Danet-Desnoyers et al., 1994; Spencer et al., 2007a; Dorniak et al., 2013). Second, IFNT increases uterine production of PGEs (PGE1 and PGE2) and PGE blocks the action of $\mathrm{PGF}$ at the $\mathrm{CL}$, maintaining $\mathrm{CL}$ function (Ottobre et al., 1984; Silvia et al., 1984a, b; Wiltbank and Ottobre, 2003; Krishnaswamy et al., 2009; Weems et al., 2011, 2012; Lee et al., 2012). Third, recent convincing evidence demonstrates that IFNT exits the uterine lumen and interacts directly with the CL and may directly block PGF action at the CL (Gifford et al., 2007; Oliveira et al., 2008; Bott et al., 2010; Hansen et al., 2010; Antoniazzi et al., 2013).

Although it will not be possible in this manuscript to definitely select which of these endocrine mechanism(s) is most important in maintenance of the CL during early pregnancy, some perspective can be thought-provoking. Although the exit of IFNT from the uterus into the systemic circulation seems irrefutable, the systemic mechanism required for this pathway is not consistent with most of the older studies that definitely show a local and not a systemic mechanism involved in CL maintenance in ruminants. Thus, the third mechanism is unlikely to be the sole anti-luteolytic mechanism, although, recent studies showed that endocrine delivery of IFNT, via uterine or jugular vein, protected the ovine CL from the luteolytic actions of PGF, maintaining intraluteal and circulating P4 and CL volume (Antoniazzi et al., 2013). Nevertheless, it seems 
possible that endocrine delivery of IFNT could still be acting on the uterine endometrial cells. Related to the first mechanism, circulating PGF is generally found to be higher in the pregnant than the non-pregnant ruminant (Lewis et al., 1977; Vincent and Inskeep 1986; Arosh et al., 2004), although pulses of PGF may differ in pregnant and non-pregnant ruminants. Finally, previous studies have indicated that the CL of pregnancy has reduced sensitivity to PGF (Silvia and Niswender, 1984, 1986; Silvia et al., 1984a). Much of this resistance to PGF action is ascribed to actions of PG E2 and E1 (PGE) coming from the pregnant uterus. In addition, PGE2, but not IFNT, is transported through the utero-ovarian plexus consistent with a local signal occurring during early pregnancy (Lee et al., 2012). Further, the PGE2:PGF2 $\alpha$ ratio in the utero ovarian vein was $\sim 72$-fold higher, and, in the ovarian artery, was $\sim 115$-fold higher on day 16 of pregnancy versus the estrous cycle of ewes, indicating the efficiency of uteroovarian PGE2 transport. Based on all of these various findings, it seems likely that uterine PGE, secreted in response to IFNT from the elongating embryo, has a key role in protection of the CL from luteolysis during early pregnancy (day 18-25 in cattle).

\section{Period III. Prevention of later luteolysis during pregnancy - day 30-60 of pregnancy}

The second month of pregnancy is not a typical time to think of luteolysis. However, IFNT is likely to no longer be a major factor in maintaining the $\mathrm{CL}$ during the second month of pregnancy since IFNT secretion from the developing conceptus peaks by day 23 of pregnancy and then dramatically decreases during the next few weeks (Godkin et al., 1988; Stojkovic et al., 1995). This provokes the obvious question: What maintains the CL after day 30 of pregnancy when IFNT is no longer present? Related to this question is the observation of pregnancy loss during 30-60 days of pregnancy. For example, we recently summarized the results from 46 recent studies and $\sim 25,000$ pregnancies that were evaluated by ultrasound on $\sim$ day 32 and again at $\sim$ day 60 and found $11.95 \%$ pregnancy loss during this period (Wiltbank et al., 2016). The pregnancy loss during this time period is even greater for clones. The primary cause of pregnancy loss during this period could be initial embryonic death and subsequent luteolysis or, alternatively, could be initiated by inappropriate luteolysis during this period followed by loss of the pregnancy (Giordano et al., 2010). No studies have clearly differentiated these two distinct causes.

We became more interested in luteolysis during this time period, based on recent observations that we made on timing of CL regression in accessory CL that are contralateral to the pregnancy (Wiltbank et al., 2016). In this experiment, we induced accessory CL in lactating cows by treatment with $\mathrm{GnRH}$ on day 5 after AI. Pregnant cows could therefore have an accessory CL present on either the same side as the pregnancy (ipsilateral) or on the opposite ovary (contralateral). Intriguingly, although ipsilateral CL rarely regressed, almost all contralateral CL regressed during the pregnancy. Of particularly interest, most accessory CL regressed during the second month of pregnancy. Thus, mechanisms are present on the same side as the pregnancy that allow maintenance of the ipsilateral CL, whereas, in the contralateral horn, mechanisms occur that result in regression of the CL. This result also demonstrates that local and not systemic mechanisms are responsible for maintenance or regression of the CL during this period.

What are the local mechanisms that result in maintenance of the CL during the second month of pregnancy, but that are not present, at least in sufficient quantities, to maintain the $\mathrm{CL}$ on the contralateral ovary? There are a few things to consider. First, it seems likely that the contralateral $\mathrm{CL}$ regresses due to PGF secretion from the contralateral uterine horn, since CL do not undergo spontaneous regression in ruminants with the uterus removed (Wiltbank and Casida, 1956; Mapletoft et al., 1976b). Related to this idea, responsiveness to oxytocin and the ability of the uterus to synthesize and secrete PGF persists throughout pregnancy with increases in concentrations of PGFM of approximately 6-fold when oxytocin is administered to cows between day 50 and 280 of pregnancy (Schallenberger et al., 1989; Fuchs et al., 1996). Second, the uterine horns were not isolated in our experiment and therefore whatever local agent is involved in this process must have a difference in action on the ipsilateral than the contralateral ovary. Thus, there could be a protective substance that is present in larger concentrations on the ipsilateral than the contralateral side. Nevertheless, the most likely explanation, in our opinion, is that the ipsilateral uterine horn has greater blood flow than the contralateral horn, as previously reported (Ford et al., 1979; Ford and Chenault, 1981; Panarace et al., 2006). Thus in this scenario, high uterine blood flow would not allow efficient transfer of uterine-secreted PGF from the uterine vein to the ovarian artery on the ipsilateral side but efficient PGF transport would continue to occur on the contralateral side, potentially due to reduced uterine blood flow (Ford et al., 1979). Thus, the blood flow explanation is the simplest explanation for the differential CL regression between ipsilateral and contralateral ovaries, although differential secretion of PGF or a luteal protective substance cannot be ruled out at this time.

One topic to consider is whether contralateral CL regression may represent a condition that is germane to the practical issue of pregnancy loss during the second month of pregnancy. Since pregnancy loss can be initiated by death of the embryo or alternatively by regression of the CL (Kastelic et al., 1991; Giordano et al., 2012), it seems likely that any losses due to CL regression utilize similar mechanisms as observed with contralateral $\mathrm{CL}$ regression during this time. Thus, a pregnancy that had not increased uterine blood flow sufficiently between 30 and 60 days of pregnancy, would be susceptible to loss by uterine-derived PGF. We speculate that PGF is secreted by the uterine horns throughout pregnancy, but the elevated uterine blood 
flow does not allow this PGF to be transferred to the ovarian artery. Obviously a great deal of research remains to be done to fully explain this potentially critical period for CL regression or maintenance.

\section{Period IV. Parturition-induced luteolysis- day 270- 290 of pregnancy}

In ruminants, the signal to end gestation arises from the fetus. It appears that the timing of parturition is encoded in the fetal genome and the mechanisms are activated by specific developmental events that occur in the developing fetus (Jenkin and Young, 2004). The signal from the fetus to initiate parturition in ruminants has been clearly shown to be the glucorticoid, cortisol, coming from the maturing hypothalamo-pituitaryadrenal axis. The circulating cortisol concentrations increase exponentially during the final weeks of gestation, producing what is termed the "cortisol surge" (Poore et al., 1998). When the cortisol surge is mimicked by treatment of the lamb with betamethasone (glucocorticoid), a consistent change in gene expression happened at specific times after treatment: placental aromatase mRNA increased by $14 \mathrm{~h}$, endometrial luminal epithelial cells dramatically increased E2 receptor expression by $28 \mathrm{~h}$, and increased oxytocin mRNA and oxytocin binding at $28 \mathrm{~h}$, with a consistent increase in electromyographic uterine contractile activity at 48-50 h, with definitive labor onset occurring at $56.6 \pm 0.8 \mathrm{~h}$ after treatment (Wathes et al., 1996). Thus, a similar sequence of events may occur in the uterus during parturition as occurs at the normal time of luteolysis at day 18-20, with first E2 receptor expression, then activation of the E2 receptors by circulating $\mathrm{E} 2$, and rapid induction of oxytocin receptors. Oxytocin binding to oxytocin receptors is likely to be driving myometrial contractions during labor, and induction of oxytocin receptors was observed during natural parturition (Wathes et al., 1996) but not during betamethasone-induced parturition (Leung et al., 1999). It seems likely that activation of oxytocin receptors by pulses of oxytocin underlies the large amount of PGF secretion and regression of the CL before parturition.

Figure 5 shows the changes in hormonal concentrations near the time of parturition in Holstein cattle (From adaptation of Rasmussen et al., 1996; Mattos et al., 2004). Concentrations of P4 remain elevated until about $36 \mathrm{~h}$ prior to calving and then promptly decrease to less than half the concentrations at $24 \mathrm{~h}$ before calving and reaching basal concentrations by $12 \mathrm{~h}$ before calving (Rasmussen et al., 1996). The circulating concentrations of PGFM follow an opposite pattern with basal concentration up until about $48 \mathrm{~h}$ prior to calving when circulating PGFM starts to dramatically increase (Mattos et al., 2004), most likely due to increased secretion by cells of the uterus. After parturition, concentrations of PGFM remain elevated, consistent with secretion from the uterus since the placenta has been lost by $24 \mathrm{~h}$ after parturition. The PGFM concentrations near this time are more than 5fold greater $(2000 \mathrm{pg} / \mathrm{ml})$ than the peak concentrations of PGFM in a luteolytic pulse (300-400 pg/ml during peak luteolysis) during normal luteolysis on day 18-20 (Ginther et al., 2010). Circulating E2 concentrations also increase dramatically and peak at more than 600 $\mathrm{pg} / \mathrm{ml}$ or almost 100 -fold greater than the peak circulating E2 concentrations near estrus (Sartori et al., 2004). This E2 is coming from the placenta, as evidenced by the dramatic decrease in cows with normal placental loss after parturition and continued elevation in cows with retained placenta (Rasmussen et al., 1996).

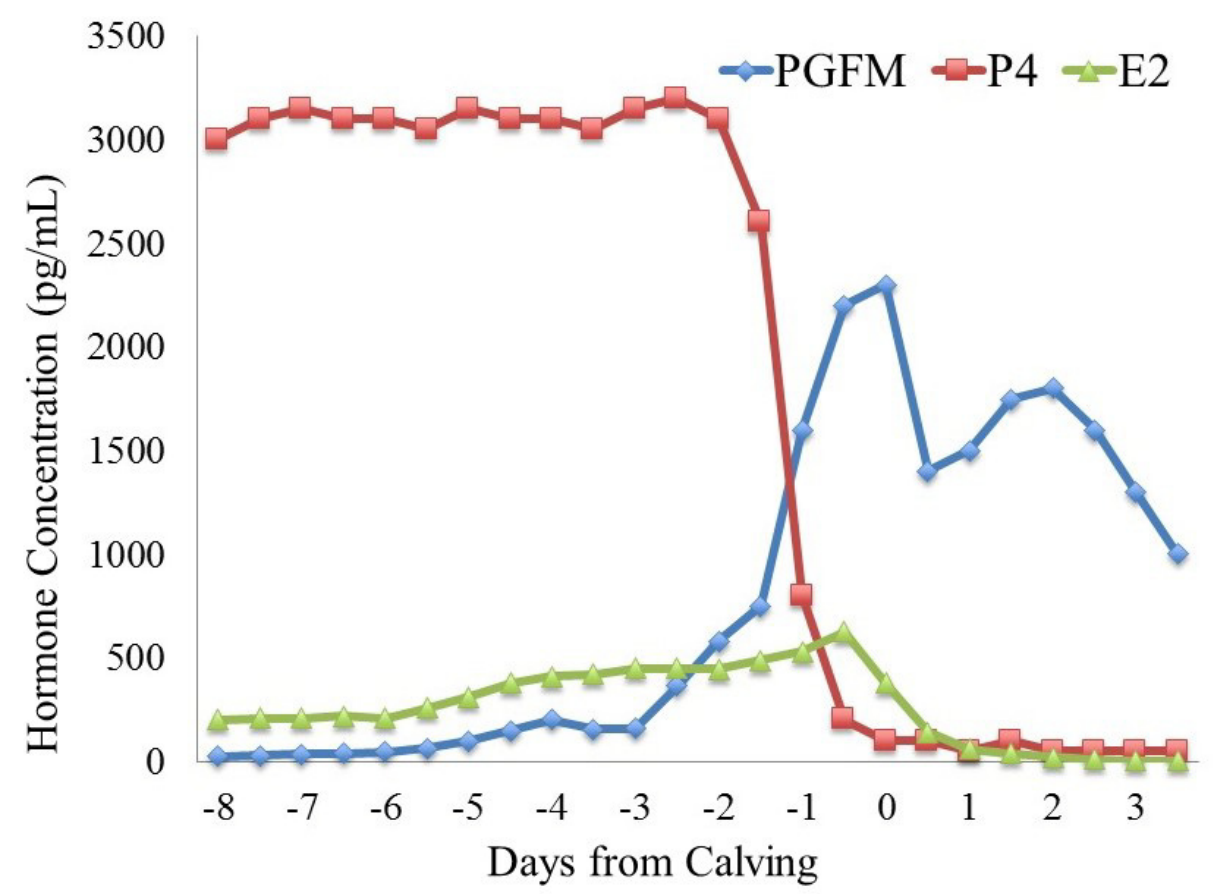

Figure 5. Circulating concentrations of progesterone (P4), estradiol (E2), and PGFM, normalized to the time of parturition in Holstein dairy cattle. From Rasmussen et al. (1996) and Mattos et al. (2004). 
There are dramatic changes in PG production near parturition from different tissues and due to different regulatory mechanisms. During the last 15-20 days of gestation there is an increase in PGE2 in the fetal circulation, closely matching the slow increase in fetal cortisol during this time. There is also the dramatic increase in PGF secretion, reflected in the increase in PGFM, however this is a late event occurring within 2 days of parturition. The PGE2 originates from the placenta due to induction of $\mathrm{PGH} 2$ in placental cells by the low amounts of cortisol that begin to come from the developing fetus. This increase in PGE2 secretion is not dependent upon circulating E2, since treatment with an aromatase inhibitor does not alter the increase in PGE2 in fetal circulation (Whittle et al., 2000). Interestingly, this PGE2 may be important for induction of aromatase near the time of parturition which drives the dramatic increase in E2 production by the placenta Subsequently, rising cortisol, combined with the rising E2 concentrations, now induce $\mathrm{PGH} 2$ expression in maternal uterine cells and this causes the dramatic increase in PGF secretion observed just before parturition. That both E2 and cortisol are required for the increase in PGFM is demonstrated by the dramatic increase in PGFM $(>500 \mathrm{pg} / \mathrm{ml})$ in response to cortisol in the presence of physiological concentrations of E2 but no increase when cortisol is given in the absence of E2 due to simultaneous treatment with an aromatase inhibitor (Whittle et al., 2000).

There is substantial evidence that PGF has an obligatory role in parturition-induced luteolysis, as seen by the patterns of PGFM discussed above. Treatments that initiate premature delivery, also induce the characteristic increase in PGF secretion from the uterus before luteolysis and parturition (Wu et al., 2004). Inhibition of PGF production by treatment with nonsteroidal anti-inflammatory drugs (NSAIDs) will delay or prevent luteolysis near parturition (Jenkin, 1992; Sugimoto et al., 1998; Jenkin and Young, 2004). Finally, mice that have a knockout of the PGF receptor do not undergo luteolysis and therefore do not go through normal parturition, unless the ovaries/CL are removed (Sugimoto et al., 1997; Tsuboi et al., 2003).

\section{Conclusions}

Three of the four time period of luteolysis have been well-characterized. In each case, there is a clear role for E2 receptors in the induction of oxytocin receptors. This happens prematurely in the short luteal phase, also during the normal luteolytic process at about day 18-20 in cattle, and during the luteolytic process that results in parturition. After oxytocin receptors are present, oxytocin then induces secretion of PGF from the uterine endometrial cells in each of these luteolytic events. Thus, uterine PGF secretion is an essential part of each time of luteolysis that has been well-studied. In the short luteal phase and normal luteolysis, uterineproduced PGF is transferred through a local venoarterial pathways and sufficient PGF eventually reaches to $\mathrm{CL}$ to result in luteolysis, following multiple PGF pulses. During parturition, it seems likely that there are such high quantities of PGF being secreted by the uterus (10-fold higher PGFM) that PGF may reach the CL through the systemic circulation. After completing this review of the literature, it clearly does not seem typical and the authors could find no convincingly-researched physiological situation that demonstrates spontaneous regression of the ruminant $\mathrm{CL}$ in the absence of uterinederived or exogenous PGF. Thus, the concept that PGF causes all types of luteolysis in ruminants is strongly supported by each type of well-investigated luteolytic event.

The key question that puzzles us after this review of the literature is how is the CL protected from luteolysis during pregnancy, after the interval when IFNT is secreted by the ruminant embryo. During most of pregnancy, the uterus will respond to oxytocin with PGF pulses (Schallenberger et al., 1989; Fuchs et al., 1996) but still luteolysis does not occur. For us, the two most logical responses to this physiological question are: 1) There is a substance protecting the CL from PGF action during much of pregnancy or 2) PGF does not reach the CL during most of pregnancy, perhaps due to lack of PGF transport via the normal local transport pathways. Future research will continue to unlock this and other mysteries about the endocrine and cellular/molecular mechanisms that produce luteolysis and protection from luteolysis in ruminants.

\section{Acknowledgments}

Grant support from Wisconsin Experiment Station, FAPESP and CNPq of Brazil, and BARD.

\section{References}

Antoniazzi AQ, Webb BT, Romero JJ, Ashley RL, Smirnova NP, Henkes LE, Bott RC, Oliveira JF, Niswender GD, Bazer FW, Hansen TR. 2013. Endocrine delivery of interferon tau protects the corpus luteum from Prostaglandin F2 alpha-induced luteolysis in ewes. Biol Reprod, 88:1-12.

Araujo RR, Ginther OJ, Ferreira JC, Palhao MM, Beg MA, Wiltbank MC. 2009. Role of follicular estradiol-17beta in timing of luteolysis in heifers. Biol Reprod, 81:426-437.

Arosh JA, Banu SK, Chapdelaine P, Madore E, Sirois J, Fortier MA. 2004. Prostaglandin biosynthesis, transport, and signaling in corpus luteum: a basis for autoregulation of luteal function. Endocrinology, 145:2551-2560.

Atli MO, Mehta V, Baruah KK, Bender RW, Bastos MR, Guenther JN, Luo W, Vezina CM, Wiltbank MC. 2011. Induction and localization of five immediate early genes (IEGs) in the bovine corpus luteum (CL) at 30 min after prostaglandin F2 alpha (PGF) treatment. Reprod Domest Anim, 46:87-88.

Atli MO, Bender RW, Mehta V, Bastos MR, Luo WX, Vezina CM, Wiltbank MC. 2012. Patterns of gene expression in the bovine corpus luteum following repeated intrauterine infusions of low doses of prostaglandin F2alpha. Biol Reprod, 86:130:1-13.

Barrett S, Blockey MAD, Brown JM, Cumming IA, 
Goding JR, Mole BJ, Obst JM. 1971. Initiation of oestrous cycle in ewe by infusions of PGF-2alpha- to autotransplanted ovary. J Reprod Fertil, 24:136-137.

Bazer FW, Spencer TE, Ott TL. 1997. Interferon tau: a novel pregnancy recognition signal. Am J Reprod Immunol, 37:412-420.

Beard AP, Hunter MG. 1994. Effects of bovine follicular fluid and exogenous oestradiol on the GnRHinduced short luteal phase in anoestrous ewes. $J$ Reprod Fertil, 100:211-217.

Beard AP, Hunter MG. 1996. Effects of exogenous oxytocin and progesterone on GnRH-induced short luteal phases in anoestrous ewes. J Reprod Fertil, 106:55-61

Berardinelli JG, Butcher RL. 1979. Source of progesterone in prepuberal ewes. Biol Reprod, 20:A114A115.

Berardinelli JG, Dailey RA, Butcher RL, Inskeep EK. 1979. Source of progesterone prior to puberty in beef heifers. J Anim Sci, 49:1276-1280.

Bott RC, Ashley RL, Henkes LE, Antoniazzi AQ, Bruemmer JE, Niswender GD, Bazer FW, Spencer TE, Smirnova NP, Anthony RV, Hansen TR. 2010. Uterine vein infusion of interferon Tau (IFNT) extends luteal life span in ewes. Biol Reprod, 82:725-735.

Braden TD, King ME, Odde KG, Niswender GD. 1989a. Development of preovulatory follicles expected to form short-lived corpora lutea in beef cows. J Reprod Fertil, 85:97-104.

Braden TD, Sawyer HR, Niswender GD. 1989b. Functional and morphological characteristics of the first corpus luteum formed after parturition in ewes $J$ Reprod Fertil, 86:525-533.

Collins WE, Inskeep EK, Howland BE, Pope AL, Casida LE. 1966. Effect of hysterectomy and corpus luteum induction on pituitary-ovarian relationships in ewes. J Anim Sci, 25:87-96.

Cooper DA, Carver DA, Villeneuve P, Silvia WJ, Inskeep EK. 1991. Effects of progestagen treatment on concentrations of prostaglandins and oxytocin in plasma from the posterior vena cava of post-partum beef cows. J Reprod Fertil, 91:411-421.

Copelin JP, Smith MF, Garverick HA, Youngquist RS. 1987. Effect of the uterus on subnormal luteal function in anestrous beef-cows. J Anim Sci, 64:15061511.

Copelin JP, Smith MF, Garverick HA, Youngquist RS, Mcvey WR, Inskeep EK. 1988. Responsiveness of bovine corpora-lutea to prostaglandin-F2-alpha comparison of corpora-lutea anticipated to have short or normal lifespans. J Anim Sci, 66:1236-1245.

Copelin JP, Smith MF, Keisler DH, Garverick HA. 1989. Effect of active immunization of pre-partum and post-partum cows against prostaglandin F-2 alpha on lifespan and progesterone secretion of short-lived corpora lutea. J Reprod Fertil, 87:199-207.

Danet-Desnoyers G, Wetzels C, Thatcher WW. 1994. Natural and recombinant bovine interferon-tau regulate basal and oxytocin-induced secretion of prostaglandins F2a and E2 by epithelial cells and stromal cells in the endometrium. Reprod Fertil Dev, 6:193-202.

Del Campo MR, Rowe RF, French LR, Ginther OJ.
1977. Unilateral relationship of embryos and the corpus luteum in cattle. Biol Reprod, 16:580-585.

Del Campo MR, Mapletoft RJ, Rowe RF, Critser JK, Ginther OJ. 1980. Unilateral utero-ovarian relationship in pregnant cattle and role of uterine vein. Theriogenology, 14:185-193.

Dorniak P, Bazer FW, Spencer TE. 2013. Physiology and endocrinology symposium: biological role of interferon tau in endometrial function and conceptus elongation. J Anim Sci, 91:1627-1638.

Ellinwood WE, Nett TM, Niswender GD. 1978. Ovarian vasculature: structure and function. In: Jones RE (Ed.). The Vertebrate Ovarian: comparative biology and evolution. New York, NY: Plenum. pp. 583-614.

Fairclough RJ, Smith JF, McGowan LT. 1981. Prolongation of the estrous-cycle in cows and ewes after passive-immunization with PGF antibodies. $J$ Reprod Fertil, 62:213-219.

Fallon GR. 1958. Some aspects of oestrum in cattle, with reference to fertility on artificial insemination. I. The pattern of oestrous cycles. Queens J Agric Anim Sci, 15:25-34.

Ford SP, Chenault JR, Echternkamp SE. 1979. Uterine blood-flow of cows during the estrous-cycle and early-pregnancy - effect of the conceptus on the uterine blood-supply. J Reprod Fertil, 56:53-62.

Ford SP, Chenault JR. 1981. Blood-flow to the corpus luteum-bearing ovary and ipsilateral uterine horn of cows during the estrous-cycle and early-pregnancy. $J$ Reprod Fertil, 62:555-562.

Fortier MA, Arosh JA, Banu S, Madore E, Parent J, Chapdelaine P. 2004. A novel integrated view of the role of prostaglandins for recognition and establishment of pregnancy in ruminants. $J$ Endocrinol Reprod, 8:4568.

Fraenkel L, Cohn F. 1901. Experimentelle untersuchungen des corpus luteum auf die insertion des eies (Theorie von Born). Anat Anz, 20:294-300.

Fraenkel L. 1910. Neue experiment zur function des corpus luteum. Arch Gynakol, 91:705-730.

Fuchs AR, Rollyson MK, Meyer M, Fields MJ, Minix JM, Randel RD. 1996. Oxytocin induces prostaglandin F-2 alpha release in pregnant cows: influence of gestational age and oxytocin receptor concentrations. Biol Reprod, 54:647-653.

Garverick HA, Parfet JR, Lee CN, Copelin JP, Youngquist RS, Smith MF. 1988. Relationship of preovulatory and post-ovulatory gonadotropin concentrations to subnormal luteal function in postpartum beef-cattle. J Anim Sci, 66:104-111.

Garverick HA, Moser MT, Keisler DH, Hamilton SA, Roberts RM, Smith MF. 1992a. Luteal function after intrauterine infusion of recombinant bovine interferon alpha-1 into postpartum beef cows expected to have short or normal luteal phases. J Reprod Fertil, 94:319-325.

Garverick HA, Zollers WG, Smith MF. 1992b. Mechanisms associated with corpus-luteum life-span in animals having normal or subnormal luteal function. Anim Reprod Sci, 28:111-124.

Gifford CA., Racicot K, Clark DS, Austin KJ, Hansen TR, Lucy MC, Davies CJ, Ott TL. 2007. 
Regulation of interferon-stimulated genes in peripheral blood leukocytes in pregnant and bred, nonpregnant dairy cows. J Dairy Sci, 90:274-280.

Ginther OJ, Del Campo CH. 1974. Vascular anatomy of uterus and ovaries and unilateral luteolytic effect of uterus - cattle. Am J Vet Res, 35:193-203.

Ginther OJ, Silva LA, Araujo RR, Beg MA. 2007. Temporal associations among pulses of 13,14-dihydro15-keto-PGF(2alpha), luteal blood flow, and luteolysis in cattle. Biol Reprod, 76:506-513.

Ginther OJ, Araujo RR, Palhao MP, Rodrigues BL, Beg MA. 2009. Necessity of sequential pulses of prostaglandin F2alpha for complete physiologic luteolysis in cattle. Biol Reprod, 80:641-648.

Ginther OJ, Beg MA. 2009. Concentrations of circulating hormones normalized to pulses of a prostaglandin F-2 alpha metabolite during spontaneous luteolysis in mares. Theriogenology, 72:1111-1119.

Ginther OJ, Shrestha HK, Fuenzalida MJ, Shahiduzzaman AKM, Beg MA. 2010. Characteristics of pulses of 13,14-dihydro-15-keto-prostaglandin F2alpha before, during, and after spontaneous luteolysis and temporal intrapulse relationships with progesterone concentrations in cattle. Biol Reprod, 82:1049-1056.

Ginther OJ, Khan FA, Hannan MA, Beg MA. 2012. Temporal interrelationships at 15-min intervals among oxytocin, LH, and progesterone during a pulse of a prostaglandin F2 alpha metabolite in heifers. Anim Reprod Sci, 133:63-70.

Giordano JO, Guenther JN, Lopes G, McGrath MF, Fricke PM. 2010. Serum pregnancy-associated glycoprotein (PAG) and progesterone concentrations after induction of pregnancy loss at day 39 of gestation in lactating dairy cows. J Dairy Sci, 93:81-82.

Giordano JO, Guenther JN, Lopes G, Fricke PM. 2012. Changes in serum pregnancy-associated glycoprotein, pregnancy-specific protein B, and progesterone concentrations before and after induction of pregnancy loss in lactating dairy cows. J Dairy Sci, 95:683-697.

Goding JR, McCracken JA, Baird DT. 1967. Study of ovarian function in ewe by means of a vascular autotransplantation technique. J Endocrinol, 39:37-52.

Godkin JD, Bazer FW, Moffatt J, Sessions F, Roberts RM. 1982. Purification and properties of a major, low molecular weight protein released by the trophoblast of sheep blastocysts at day 13-21. J Reprod Fertil, 65:141-150.

Godkin JD, Bazer FW, Roberts RM. 1984a. Ovine trophoblast protein 1 , an early secreted blastocyst protein, binds specifically to uterine endometrium and affects protein synthesis. Endocrinology, 114:120-130.

Godkin JD, Bazer FW, Thatcher WW, Roberts RM. 1984b. Proteins released by cultured day 15-16 conceptuses prolong luteal maintenance when introduced into the uterine lumen of cyclic ewes. $J$ Reprod Fertil, 71:57-64.

Godkin JD, Lifsey BJ, Gillespie BE. 1988. Characterization of bovine conceptus proteins produced during the periattachment and postattachment periods of early pregnancy. Biol Reprod, 38, 703-711.

Godkin JD, Smith SE, Johnson RD, Dore JJ. 1997.
The role of trophoblast interferons in the maintenance of early pregnancy in ruminants. Am J Reprod Immunol, 37:137-143.

Gutknecht GD, Cornette JC, Pharriss BB. 1969.

Antifertility properties of prostaglandin F2. Biol Reprod, 1:367-371.

Hansel W. 1966. Luteotrophic and luteolytic mechanisms in bovine corpora lutea. $J$ Reprod Fertil Suppl, 1:33-48.

Hansen TR, Henkes LK, Ashley RL, Bott RC, Antoniazzi AQ, Han H. 2010. Endocrine actions of interferon-tau in ruminants. Soc Reprod Fertil Suppl, 67:325-340.

Hinshelwood MM, Hansen PJ, Hauser ER. 1982. Short estrous cycles in postpartum cows as influenced by level of milk-production, suckling, diet, season of calving and interval to $1 \mathrm{st}$ estrus. Theriogenology, 18:383-392.

Hunter MG, Southee JA, Mcleod BJ, Haresign W. 1986. Progesterone pretreatment has a direct effect on GnRH-induced preovulatory follicles to determine their ability to develop into normal corpora lutea in anestrous ewes. J Reprod Fertil, 76:349-363.

Hunter MG., Ayad VJ, Gilbert CL, Southee JA, Wathes DC. 1989. Role of prostaglandin-F-2-alpha and oxytocin in the regression of GnRH-induced abnormal corpora lutea in anestrous ewes. J Reprod Fertil, 85:551-561.

Hunter MG. 1991. Characteristics and causes of the inadequate corpus luteum. $J$ Reprod Fertil, 43:91-99.

Inskeep EK, Butcher RL. 1966. Local component of utero-ovarian relationships in ewe. J Anim Sci, 25:11641168.

Inskeep EK, Braden TD, Lewis PE, Garciawinder M, Niswender GD. 1988. Receptors for luteinizinghormone and follicle-stimulating-hormone in largest follicles of postpartum beef-cows. Biol Reprod, 38:587591 .

Jenkin G. 1992. Oxytocin and prostaglandin interactions in pregnancy and at parturition. $J$ Reprod Fertil Suppl, 45:97-111.

Jenkin G, Young IR. 2004. Mechanisms responsible for parturition; the use of experimental models. Anim Reprod Sci, 82/83:567-581.

Jocelyn HD, Setchell BP. 1972. An annotated translation of Regnier deGraaf's new treatise concerning the generative organs of women (1672). J Reprod Fertil Suppl, 17:77-206.

Johnson GA, Austin KJ, Collins AM, Murdoch WJ, Hansen TR. 1999. Endometrial ISG17 mRNA and a related mRNA are induced by interferon-tau and localized to glandular epithelial and stromal cells from pregnant cows. Endocrine, 10:243-252.

Kanai N, Lu R, Satriano JA, Bao Y, Wolkoff AW, Schuster VL. 1995. Identification and characterization of a prostaglandin transporter. Science, 268:866-869.

Kastelic JP, Northey DL, Ginther OJ. 1991. Spontaneous embryonic death on days 20 to 40 in heifers. Theriogenology, 35:351-363.

Kindahl H, Edqvist LE Bane A, Granstrom E. 1976. Blood-levels of progesterone and 15-keto-13,14dihydro-prostaglandin-F(alpha-2) during normal 
estrous-cycle and early-pregnancy in heifers. Acta Endocrinol, 82:134-149.

Knickerbocker JJ, Thatcher WW, Bazer FW, Barron DH, Roberts RM. 1986. Inhibition of uterine prostaglandin-F2 alpha production by bovine conceptus secretory proteins. Prostaglandins, 31:777-793.

Knickerbocker JJ, Wiltbank MC, Niswender GD. 1988. Mechanisms of luteolysis in domestic livestock. Domest Anim Endocrinol, 5:91-107.

Krishnaswamy $\mathbf{N}$, Chapdelaine $\mathbf{P}$, Tremblay JP, Fortier MA. 2009. Development and characterization of a simian virus 40 immortalized bovine endometrial stromal cell line. Endocrinology, 150:485-491.

Lamond DR, Drost M, McCracken JA, Lamond DR 1973. Countercurrent transfer of prostaglandin in ewe. Prostaglandins, 3:691-702.

Lee J, McCracken JA, Banu SK, Rodriguez R, Nithy TK, Arosh JA. 2010. Transport of prostaglandin F-2 alpha pulses from the uterus to the ovary at the time of luteolysis in ruminants is regulated by prostaglandin transporter-mediated mechanisms. Endocrinology, 151:3326-3335.

Lee J, McCracken JA, Stanley JA, Nithy TK, Banu SK, Arosh JA. 2012. Intraluteal prostaglandin biosynthesis and signaling are selectively directed towards PGF2alpha during luteolysis but towards PGE2 during the establishment of pregnancy in sheep. Biol Reprod, 87:97.

Lee J, McCracken JA., Banu SK, Arosh JA. 2013. Intrauterine inhibition of prostaglandin transporter protein blocks release of luteolytic PGF2alpha pulses without suppressing endometrial expression of estradiol or oxytocin receptor in ruminants. Biol Reprod, 89:27.

Leung ST, Wathes DC, Young IR, Jenkin G. 1999. Effect of labor induction on the expression of oxytocin receptor, cytochrome $\mathrm{P} 450$ aromatase, and estradiol receptor in the reproductive tract of the late-pregnant ewe. Biol Reprod, 60:814-820.

Lewis GS, Wilson L, Jr, Wilks JW, Pexton JE, Fogwell RL, Ford SP, Butcher RL, Thayne WV, Inskeep EK. 1977. PGF2 alpha and its metabolites in uterine and jugular venous plasma and endometrium of ewes during early pregnancy. J Anim Sci, 45:320-327.

Lewis PE, Warren JE. 1977. Effect of indomethacin on luteal function in ewes and heifers. $J$ Anim Sci, 45:763-767.

Loeb L. 1927. The effects of hysterectomy on the system of sex organs and on the periodicity of the sexual cycle in the guinea pig. Am J Physiol, 83:202208.

Magnus V. 1901 Ovariets betydning for svangerskabet med saerligt hensyntil corpus luteum. No Mag Laegevidensk, 62:1138-1145.

Magnus V, Simmer HH. 1972. The first experiments to demonstrate an endocrine function of the corpus luteum. II. Ludwig Fraenkel versus Vilhelm Magnus. Sudhoffs Arch, 56:76-99.

Mapletoft RJ, Del Campo MR, Ginther OJ. 1975. Unilateral luteotropic effect of uterine venous effluent of a gravid uterine horn in sheep. Proc Soc Exp Biol Med, 150:129-133.

Mapletoft RJ, Ginther OJ. 1975. Adequacy of main uterine vein and ovarian artery in local venoarterial pathway for uterine-induced luteolysis in ewes. $\mathrm{Am} \mathrm{J}$ Vet Res, 36:957-963.

Mapletoft RJ, Del Campo MR, Ginther OJ. 1976a. Local utero-ovarian venoarterial pathway in cows. $J$ Anim Sci, 43:295-296.

Mapletoft RJ, Del Campo MR, Ginther OJ. 1976b. Local venoarterial pathway for uterine-induced luteolysis in cows. Proc Soc Exp Biol Med, 153:289294.

Mapletoft RJ, Lapin DR, Ginther OJ. 1976c. Ovarian artery as final component of local luteotropic pathway between a gravid uterine horn and ovary in ewes. Biol Reprod, 15:414-421.

Martal J, Lacroix MC, Loudes C, Saunier M, Wintenberger-Torres S. 1979. Trophoblastin, an antiluteolytic protein present in early pregnancy in sheep. J Reprod Fertil, 56:63-73.

Mattos R, Staples CR, Arteche A, Wiltbank MC, Diaz FJ, Jenkins TC, Thatcher WW. 2004. The effects of feeding fish oil on uterine secretion of $\operatorname{PGF}(2$ alpha), milk composition, and metabolic status of periparturient Holstein cows. J Dairy Sci, 87:921-932.

McCracken JA. 1971. Prostaglandin-F2-Alpha and corpus luteum regression. Ann NY Acad Sci, 180:456472.

McCracken JA, Samuelss B, Goding JR, Glew ME, Green K, Carlson JC, Baird DT. 1972. ProstaglandinF2-alpha identified as a luteolytic hormone in sheep. Nature New Biol, 238:129-134.

McCracken JA, Schramm W, Barcikowski B, Wilson Jr L. 1981. The identification of prostaglandin F2 alpha as a uterine luteolytic hormone and the hormonal control of its synthesis. Acta Vet Scand Suppl, 77:71-88

McCracken JA, Custer EE, Lamsa JC. 1999. Luteolysis: a neuroendocrine-mediated event. Physiol Rev, 79:263-323.

McCracken JA, Lee J, Banu SK, Rodriguez R, Nithy TK, Arosh JA. 2010. The countercurrent transfer of PGF(2 alpha) from the uterus to the ovary at the time of luteolysis in ruminants is controlled by a prostaglandin transporter-mediated mechanism. Soc Reprod Fertil, 67:569-569.

McCracken JA, Lee J, Yang B, Nithy TK, Banu SK, Bazer FW, Arosh JA. 2011. Inhibition of the prostaglandin transporter protein suppresses luteolytic pulses of PGF2alpha from the ovine uterus. Biol Reprod, 85(suppl. 1):374.

McCracken JA, Custer EE, Schreiber DT, Tsang PCW, Keator CS, Arosh JA. 2012. A new in vivo model for luteolysis using systemic pulsatile infusions of PGF(2 alpha). Prostaglandins Other Lipid Mediat, 97:90-96

Michael AE, Abayasekara DRE, Webley GE. 1993. The luteotrophic actions of prostaglandins E2 and F2alpha on dispersed marmoset luteal cells are differentially mediated by cyclic AMP and protein kinase C. J Endocrinol, 138:291-298.

Miyamoto A, Vonlutzow H, Schams D. 1993. Acute actions of prostaglandin F-2alpha, prostaglandin E2, and prostaglandin I 2 in microdialyzed bovine corpus luteum 
in vitro. Biol Reprod, 49:423-430.

Moor RM, Rowson LE. 1966. The corpus luteum of the sheep: functional relationship between the embryo and the corpus luteum. J Endocrinol, 34:233-239.

Moor RM. 1968. Effect of embryo on corpus luteum function. J Anim Sci, 27(suppl. 1):97-118.

Moor RM, Rowson LEA, Hay MF, Caldwell BV. 1969. The corpus luteum of the sheep: effect of the conceptus on luteal function at several stages during pregnancy. J Endocrinol, 43:301-307.

Northey DL, French LR. 1980. Effect of embryo removal and intrauterine infusion of embryonic homogenates on the lifespan of the bovine corpus luteum. J Anim Sci, 50:298-302.

Oliveira JF, Henkes LE, Ashley RL, Purcell SH, Smirnova NP, Veeramachaneni DNR, Anthony RV, Hansen TR. 2008. Expression of interferon (IFN)stimulated genes in extrauterine tissues during early pregnancy in sheep is the consequence of endocrine IFN-tau release from the uterine vein. Endocrinology, 149:1252-1259.

Ottobre JS, Vincent DL, Silvia WJ, Inskeep EK. 1984. Aspects of regulation of uterine secretion of prostaglandins during the estrous cycle and early pregnancy. Anim Reprod Sci, 7:75-100.

Panarace M, Garnil C, Marfil M, Jauregui G, Lagioia J, Luther E, Medina M. 2006. Transrectal Doppler sonography for evaluation of uterine blood flow throughout pregnancy in 13 cows. Theriogenology, 66:2113-2119.

Peters MW, Pursley JR. 2003. Timing of final GnRH of the Ovsynch protocol affects ovulatory follicle size, subsequent luteal function, and fertility in dairy cows. Theriogenology, 60:1197-1204.

Pharriss BB, Wyngarde LJ. 1969. Effect of prostaglandin F2alpha on progestogen content of ovaries of pseudopregnant rats. Proc Soc Exp Biol Med, 130:92-94

Poore KR, Young IR, Canny BJ, Thorburn GD. 1998. Studies on the role of ACTH in the regulation of adrenal responsiveness and the timing of parturition in the ovine fetus. $J$ Endocrinol, 158:161-171.

Rantala MH, Katila T, Taponen J. 2009. Effect of time interval between prostaglandin F2[alpha] and GnRH treatments on occurrence of short estrous cycles in cyclic dairy heifers and cows. Theriogenology, 71:930-938

Rasmussen FE, Wiltbank MC, Christensen J.O, Grummer RR. 1996. Effects of fenprostalene and estradiol-17 beta benzoate on parturition and retained placenta in dairy cows and heifers. J Dairy Sci, 79:227234.

Roberts RM. 1996. Interferon-tau and pregnancy. $J$ Interferon Cytokine Res, 16:271-273.

Robinson RS, Mann GE, Lamming GE, Wathes DC. 2001. Expression of oxytocin, oestrogen and progesterone receptors in uterine biopsy samples throughout the oestrous cycle and early pregnancy in cows. Reproduction, 122:965-979.

Robinson RS, Hammond AJ, Wathes DC, Hunter MG, Mann GE. 2008. Corpus luteum-endometriumembryo interactions in the dairy cow: Underlying mechanisms and clinical relevance. Reprod Domest Anim, 43:104-112.

Rowson LE, Moor RM. 1967. The influence of embryonic tissue homogenate infused into the uterus, on the life-span of the corpus luteum in the sheep. J Reprod Fertil, 13:511-516.

Royal MD, Darwash AO, Flint APE, Webb R, Woolliams JA, Lamming GE. 2000. Declining fertility in dairy cattle: changes in traditional and endocrine parameters of fertility. Anim Sci, 70:487-501.

Sá OG, Thatcher WW, Vasconcelos JLM. 2009. Effect of progesterone and/or estradiol treatments prior to induction of ovulation on subsequent luteal lifespan in anestrous Nelore cows. Anim Reprod Sci, 112:95106.

Salfen BE, Keisler DH, Smith MF, Zollers WG, Keiborzloos KR, Garverick HA. 1995. Effect of intrauterine infusion of recombinant alpha(I) 1 on lutealphase duration and oxytocin-induced release of 13,14dihydro-15-keto-prostaglandin f2-alpha in postpartum beef-cows. Anim Reprod Sci, 40:193-201.

Salfen BE, Cresswell JR, Xu ZZ, Bao B, Garverick HA. 1996. Effects of presence of a dominant follicle and estradiol on length of luteal phases in estrous cycles with two or three waves of follicular development. Biol Reprod, 54:235-235.

Sartori R, Haughian JM, Shaver RD, Rosa GJM, Wiltbank MC. 2004. Comparison of ovarian function and circulating steroids in estrous cycles of Holstein heifers and lactating cows. J Dairy Sci, 87:905-920.

Savio JD, Boland MP, Roche JF. 1990. Development of dominant follicles and length of ovarian cycles in postpartum dairy cows. $J$ Reprod Fertil, 88:581-591.

Schallenberger E, Schams D, Meyer HHD. 1989. Sequences of pituitary, ovarian and uterine hormone secretion during the first 5 weeks of pregnancy in dairy cattle. J Reprod Fertil Suppl, 37:277-286.

Schramm W, Bovaird L, Glew ME, Schramm G \& Mccracken JA. 1983. Corpus-luteum regression induced by ultralow pulses of prostaglandin-F2-alpha. Prostaglandins, 26:347-364.

Schuster VL. 1998. Molecular mechanisms of prostaglandin transport. Annu Rev Physiol, 60:221-242.

Schuster VL. 2002. Prostaglandin transport. Prostaglandins Other Lipid Mediat, 68/69:633-647.

Shirasuna K, Matsumoto H, Kobayashi E, Nitta A, Haneda S, Matsui M, Kawashima C, Kida $K$, Shimizu T, Miyamoto A. 2012. Upregulation of interferon-stimulated genes and interleukin-10 in peripheral blood immune cells during early pregnancy in dairy cows. $J$ Reprod Dev, 58:84-90.

Silvia WJ, Fitz TA, Mayan MH, Niswender GD. 1984a. Cellular and molecular mechanisms involved in luteolysis and maternal recognition of pregnancy in the ewe. Anim Reprod Sci, 7:57-74.

Silvia WJ, Niswender GD. 1984. Maintenance of the corpus luteum of early pregnancy in the ewe. 3 . Differences between pregnant and nonpregnant ewes in luteal responsiveness to prostaglandin F2-alpha. $J$ Anim Sci, 59:746-753.

Silvia WJ, Ottobre JS, Inskeep EK. 1984b. Concentrations of prostaglandin E2, prostaglandin F2 
-alpha, and 6-keto prostaglandin F1-alpha in the uteroovarian venous plasma of nonpregnant and early pregnant ewes. Biol Reprod, 30:936-944.

Silvia WJ, Niswender GD. 1986. Maintenance of the corpus luteum of early pregnancy in the ewe. 4. Changes in luteal sensitivity to prostaglandin F2-alpha throughout early pregnancy. J Anim Sci, 63:1201-1207. Simmer HH. 1971. The first experiments to demonstrate an endocrine function of the corpus luteum. On the occasion of the 100th birthday of Ludwig Fraenkel (1870-1951). Sudhoffs Arch, 55:392-417.

Smith GD, Sawyer HR, Mirando MA, Griswold MD, Sadhu A, Reeves JJ. 1996. Steady-state luteinizing hormone receptor messenger ribonucleic acid levels and endothelial cell composition in bovine normal- and short-lived corpora lutea. Biol Reprod, 55:902-909.

Smith MF, McIntush EW, Smith GW. 1994 Mechanisms associated with corpus luteum development. J Anim Sci, 72:1857-1872.

Southee JA, Hunter MG, Law AS, Haresign W. 1988. Effect of hysterectomy on the short life-cycle corpus luteum produced after $\mathrm{GnRH}$-induced ovulation in the anestrous ewe $J$ Reprod Fertil, 84:149-155.

Spencer TE, Bazer FW. 1995. Temporal and spatial alterations in uterine estrogen receptor and progesterone receptor gene expression during the estrous cycle and early pregnancy in the ewe. Biol Reprod, 53:1527-1543.

Spencer TE, Becker WC, George P, Mirando MA, Ogle TF, Bazer FW. 1995. Ovine interferon-tau inhibits estrogen-receptor up-regulation and estrogeninduced luteolysis in cyclic ewes. Endocrinology, 136:4932-4944

Spencer TE, Johnson GA, Bazer FW, Burghardt RC. 2007a. Fetal-maternal interactions during the establishment of pregnancy in ruminants. Soc Reprod Fertil Suppl, 64:379-396.

Spencer TE, Johnson GA, Bazer FW, Burghardt RC, Palmarini M. 2007b. Pregnancy recognition and conceptus implantation in domestic ruminants: Roles of progesterone, interferons and endogenous retroviruses. Reprod Fertil Dev, 19:65-78.

Spencer TE, Hansen TR. 2015. Implantation and establishment of pregnancy in ruminants. Adv Anat Embryol Cel, 216:105-135.

Staples CR, Thatcher WW, Clark JH. 1990 Relationship between ovarian activity and energy status during the early postpartum period of high producing dairy cows. J Dairy Sci, 73:938-947.

Stevenson JS, Britt JH. 1979. Relationships among luteinizing hormone, estradiol, progesterone, glucocorticoids, milk yield, body weight and postpartum ovarian activity in Holstein cows. J Anim Sci, 48:570577

Stojkovic M, Wolf E, Buttner M, Berg U, Charpigny G, Schmitt A, Brem G. 1995. Secretion of biologically-active interferon-tau by in-vitro-derived bovine trophoblastic tissue. Biol Reprod, 53:1500-1507.

Sugimoto Y, Yamasaki A, Segi E, Tsuboi K, Aze Y, Nishimura T, Oida H, Yoshida N, Tanaka T, Katsuyama M, Hasumoto $K$, Murata $T$, Hirata M, Ushikubi F, Negishi M, Ichikawa A, Narumiya S. 1997. Failure of parturition in mice lacking the prostaglandin F receptor. Science, 277:681-683.

Sugimoto Y, Segi E, Tsuboi K, Ichikawa A, Narumiya S. 1998. Female reproduction in mice lacking the prostaglandin $\mathrm{F}$ receptor. Roles of prostaglandin and oxytocin receptors in parturition. $A d v$ Exp Med Biol, 449:317-321.

Thatcher WW, Bartol FF, Knickerbocker JJ, Curl JS, Wolfenson D, Bazer FW, Roberts RM. 1984. Maternal recognition of pregnancy in cattle. J Dairy Sci, 67:2797-2811.

Tsai SJ, Wiltbank MC. 1996. Prostaglandin F-2 alpha upregulates expression of mRNA for prostaglandin $\mathrm{G} / \mathrm{H}$ synthase-2 in ovine large luteal cells. Biol Reprod, 54:179-179.

Tsai SJ, Wiltbank MC. 1997. Prostaglandin F-2 alpha induces expression of prostaglandin $\mathrm{G} / \mathrm{H}$ synthase-2 in the ovine corpus luteum: A potential positive feedback loop during luteolysis. Biol Reprod, 57:1016-1022.

Tsuboi K, Iwane A, Nakazawa S, Sugimoto Y, Ichikawa A. 2003. Role of prostaglandin H-2 synthase 2 in murine parturition: Study on ovariectomy-induced parturition in prostaglandin $\mathrm{F}$ receptor-deficient mice. Biol Reprod, 69:195-201.

Vasconcelos JLM, Sartori R, Oliveira HN, Guenther JG, Wiltbank MC. 2001. Reduction in size of the ovulatory follicle reduces subsequent luteal size and pregnancy rate. Theriogenology, 56:307-314.

Vincent DL, Inskeep EK. 1986. Role of progesterone in regulating uteroovarian venous concentrations of PGF2 alpha and PGE2 during the estrous cycle and early pregnancy in ewes. Prostaglandins, 31:715-733.

Wathes DC, Smith HF, Leung ST, Stevenson KR, Meier S, Jenkin G. 1996. Oxytocin receptor development in ovine uterus and cervix throughout pregnancy and at parturition as determined by in situ hybridization analysis. $J$ Reprod Fertil, 106:23-31.

Weems YS, Arreguin-Arevalo JA, Nett TM, Vann RC, Ford SP, Bridges PJ, Welsh TH, Jr, Lewis AW, Neuendorff DA, Randel RD, Weems CW. 2011. In vivo intra-luteal implants of prostaglandin (PG) E-1 or E-2 (PGE(1), PGE(2)) prevent luteolysis in cows. I. Luteal weight, circulating progesterone, mRNA for luteal luteinizing hormone (LH) receptor, and occupied and unoccupied luteal receptors for LH. Prostaglandins Other Lipid Mediat, 95:35-44.

Weems YS, Bridges PJ, Jeoung M, ArreguinArevalo JA., Nett TM, Vann RC, Ford SP., Lewis AW, Neuendorff DA, Welsh TH, Jr, Randel RD, Weems CW. 2012. In vivo intra-luteal implants of prostaglandin (PG) E-1 or E-2 (PGE(1), PGE(2)) prevent luteolysis in cows. II: $\mathrm{mRNA}$ for $\mathrm{PGF}(2$ alpha), EP1, EP2, EP3 (A-D), EP3A, EP3B, EP3C, EP3D, and EP4 prostanoid receptors in luteal tissue. Prostaglandins Other Lipid Mediat, 97:60-65.

White LM, Keisler DH, Dailey RA, Inskeep EK. 1987. Characterization of ovine follicles destined to form subfunctional corpora-lutea. J Anim Sci, 65:1595-1601.

Whittle WL, Holloway AC, Lye SJ, Gibb W, Challis JRG. 2000. Prostaglandin production at the onset of ovine parturition is regulated by both estrogenindependent and estrogen-dependent pathways. Endocrinology, 141:3783-3791. 
Wilson L Jr, Cenedella RJ, Butcher RL, Inskeep EK. 1972. Levels of prostaglandins in uterine endometrium during ovine estrous-cycle. J Anim Sci, 34:9399.

Wiltbank JN, Casida LE. 1956. Alteration of ovarian activity by hysterectomy. J Anim Sci, 15:134-140.

Wiltbank MC, Gallagher KP, Dysko RC, Keyes PL. 1989. Regulation of blood flow to the rabbit corpus luteum - Effects of estradiol and human chorionic gonadotropin. Endocrinology, 124:605-611.

Wiltbank MC. 1994. Cell types and hormonal mechanisms associated with mid-cycle corpus luteum function. J Anim Sci, 72:1873-1883.

Wiltbank MC, Ottobre JS. 2003. Regulation of intraluteal production of prostaglandins. Reprod Biol Endocrinol, 1:91.

Wiltbank MC, Salih SM, Atli MO, Luo W, Bormann CL, Ottobre JS, Vezina CM, Mehta V, Diaz FJ, Tsai SJ, Sartori R. 2012. Comparison of endocrine and cellular mechanisms regulating the corpus luteum of primates and ruminants. Anim Reprod, 9:242-259.
Wiltbank MC, Baez GM, Garcia-Guerra A, Toledo MZ, Monteiro PL, Melo LF, Ochoa JC, Santos JE, Sartori R. 2016. Pivotal periods for pregnancy loss during the first trimester of gestation in lactating dairy cows. Theriogenology, 86:239-253.

Wu WX, Ma XH, Coksaygan T, Chakrabarty K, Collins V, Rose J, Nathanielsz PW. 2004. Prostaglandin mediates premature delivery in pregnant sheep induced by estradiol at 121 days of gestational age. Endocrinology, 145:1444-1452.

Zalman Y, Klipper E, Farberov S, Mondal M, Wee G, Folger JK, Smith GW, Meidan R. 2012. Regulation of angiogenesis-related prostaglandin f2alpha-induced genes in the bovine corpus luteum. Biol Reprod, 86:1-10.

Zollers WG, Garverick HA, Youngquist RS, Ottobre JS, Silcox RW, Copelin JP, Smith MF. 1991. In vitro secretion of prostaglandins from endometrium of postpartum beef-cows expected to have short or normal luteal phases. Biol Reprod, 44:522-526. 